\title{
Hydrological impacts of urbanization at the catchment
} scale

Ludovic Oudin ${ }^{1}$, Bahar Salavati ${ }^{1}$, Carina Furusho-Percot ${ }^{2}$, Pierre Ribstein ${ }^{1}$, Mohamed

Saadi ${ }^{1}$

(1) Sorbonne Université, UPMC Univ Paris 06, UMR 7619 Metis, Case 105, 4 place Jussieu, F-75005 Paris, France.

(2) IRSTEA, Hydrosystems and Bioprocesses Research Unit, Parc de Tourvoie, BP 44, 92163 Antony Cedex, France.

Corresponding author. E-Mail: $\underline{\text { ludovic.oudin@upmc.fr }}$

To be submitted to Journal of Hydrology

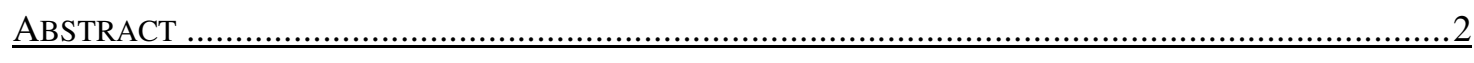

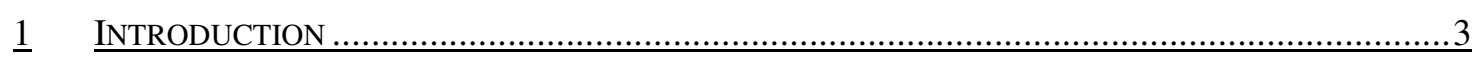

1.1 Urban transformation of river landscapes in a global context................................. 3

1.2 Identifying and quantifying the impact of urbanization on catchment response........... 3

1.3 Relating the hydrological impact on urban landscapes.........................................5

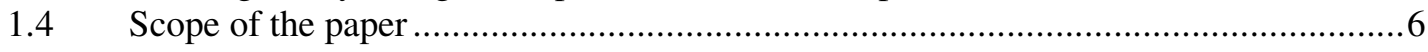

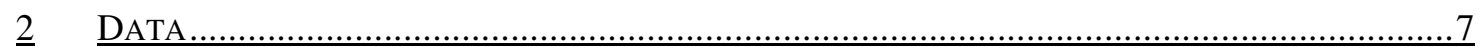

$2.1 \quad$ Catchment selection..............................................................................

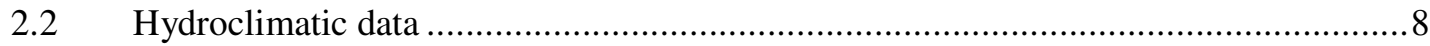

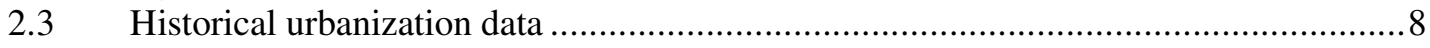

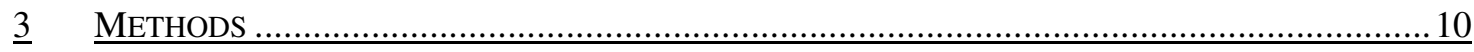

3.1 Urban landscape patterns considered....................................................... 10

3.2 Quantifying the hydrological impact of urbanization through hydrological modeling 13

3.3 Relating the hydrological impact of urbanization to urban landscape patterns............ 17

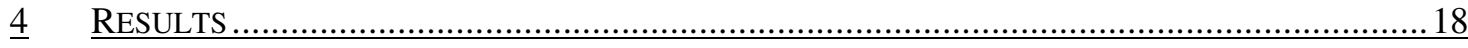

4.1 Catchment urbanization patterns ................................................................ 18

4.2 Assessment of hydrological model calibration on the preurbanization period ............24

4.3 Analysis of the hydrological impacts of catchment imperviousness .........................27

4.4 Influence of urban landscape patterns on hydrological impacts ..........................28

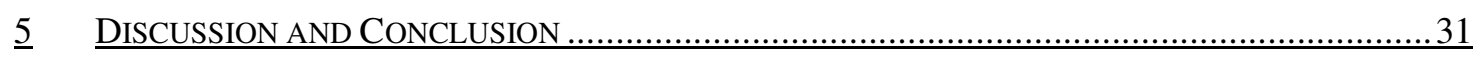

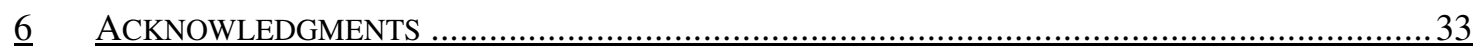

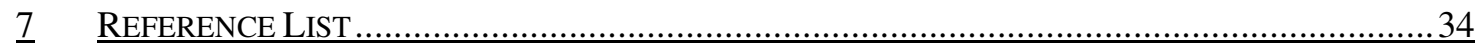

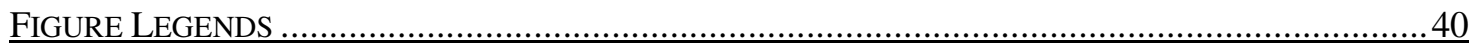

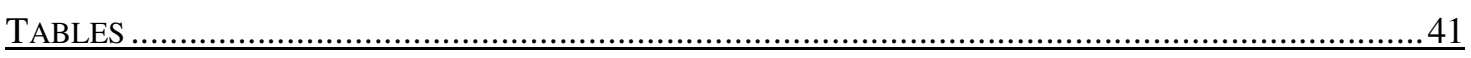




\begin{abstract}
The impacts of urbanization on floods, droughts and the overall river regime have been largely investigated in the past few decades, but the quantification and the prediction of such impacts still remain a challenge in hydrology. We gathered a sample of 142 catchments that have a documented increase in urban areas over the hydrometeorological record period in the United States. The changes in river flow regimes due to urban spread were differentiated from climate variability using the GR4J conceptual hydrological model. High, low and mean flows were impacted at a threshold of a $10 \%$ total impervious area. Moreover, the historical evolution of urban landscape spatial patterns was used to further detail the urbanization process in terms of extent and fragmentation of urban areas throughout the catchment and to help interpret the divergent impacts observed in streamflow behaviors. Regression analysis pointed out the importance of major wastewater treatment facilities that might overpass the effects of imperviousness, and therefore further research should either take them explicitly into account or select a wastewater facility-free catchment sample to clearly evaluate the impacts of urban landscape on low flows.
\end{abstract}

Keywords: rainfall-runoff modeling; urban fragmentation; total imperviousness; threshold effect; urbanization impacts. 


\section{INTRODUCTION}

\section{$2 \quad 1.1$ Urban transformation of river landscapes in a global context}

3 Today, $54 \%$ of the world's population lives in urban areas, a proportion that is expected

4 to increase to $66 \%$ by 2050 (United Nations, 2014). The environmental impacts of such

5 an increase will certainly be huge, but many facets of this impact remain difficult to

6 assess. The hydrological impact of urbanization, while largely studied for more than 50

7 years (see e.g., Leopold, 1968), is very difficult to predict and even the quantification of

8 this impact for historical urban sprawl appears difficult to assess. This is quite a problem

9 since recent urban planning or mitigation strategies could be particularly useful in the

10 near future and often involve the restoration of what is assumed to be natural

11 hydrological conditions (Trinh and Chui, 2013).

\section{$121.2 \quad$ Identifying and quantifying the impact of urbanization on catchment response}

13 Local hydrological processes can be deeply modified in urban settings; the development

14 of impervious areas alters surface infiltration of water, resulting in increased surface

15 runoff and decreased evapotranspiration and groundwater recharge (see the recent review

16 by Salvadore et al., 2015).

17 At the catchment scale (typically $10-10000 \mathrm{~km}^{2}$ ), due to the high spatial heterogeneity of 18 impervious areas, the hydrological impact of urbanization is more complex. Table 1

19 provides an overview of previous studies that investigate the hydrological impact of

20 urbanization at the catchment scale. This synthesis focuses on studies with observed

21 streamflow data along spatial or temporal gradients of urbanization; therefore studies

22 based only on simulation of hydrological models without observations (typically

23 simulations performed on land use scenario) were not included. 
Table 1: Summary of studies on the hydrological impact of urbanization. Studies involving hydrological modeling are in bold.

\begin{tabular}{|c|c|c|c|c|}
\hline $\begin{array}{l}\text { Flow } \\
\text { characteristic }\end{array}$ & Increased / emphasized & Decreased/ mitigated & $\begin{array}{l}\text { Non } \\
\text { significant / } \\
\text { non } \\
\text { systematic }\end{array}$ & Attribution of change/ main processes identified \\
\hline $\begin{array}{l}\text { High Flows } \\
\text { (storm flow) }\end{array}$ & $\begin{array}{l}\text { Burns et al., 2005; Choi et al., 2003; Diem } \\
\text { et al., 2018; Hawley and Bledsoe, 2011; } \\
\text { Hollis, 1977; H. Huang et al., 2008; S. } \\
\text { Huang et al., 2008; Konrad and Booth, } \\
\text { 2002; Mejía et al., 2015; Miller et al., } \\
\text { 2014; Miller and Hess, 2017; } \\
\text { Petchprayoon et al., 2010; Prosdocimi et } \\
\text { al., 2015; Rose and Peters, 2001; Rougé } \\
\text { and Cai, 2014; Tetzlaff et al., 2005; Tong, } \\
\text { 1990; Yang et al., } 2013\end{array}$ & & & $\begin{array}{l}\text { Reduced transit time and increased flashiness due to } \\
\text { imperviousness and/or storm water conveyance } \\
\text { systems. }\end{array}$ \\
\hline $\begin{array}{l}\text { Low Flows } \\
\text { (baseflow) }\end{array}$ & $\begin{array}{l}\text { Bhaskar et al., 2015; Burns et al., 2005; } \\
\text { Diem et al., 2018; Hollis, 1977; Konrad et } \\
\text { al., 2005; Rougé and Cai, } 2014\end{array}$ & $\begin{array}{l}\text { Braud et al., 2013; } \\
\text { Choi et al., 2003; } \\
\text { Diem et al., 2018; } \\
\text { Kauffman et al., 2009; } \\
\text { Klein, 1979; Mejía et } \\
\text { al., 2015; Rose and } \\
\text { Peters, 2001; Simmons } \\
\text { and Reynolds, } 1982\end{array}$ & $\begin{array}{l}\text { Brandes et } \\
\text { al., 2005; } \\
\text { Hejazi and } \\
\text { Moglen, } \\
\text { 2007; } \\
\text { Schwartz } \\
\text { and Smith, } \\
2014\end{array}$ & $\begin{array}{l}\text { Increased groundwater recharge due to reduced } \\
\text { evapotranspiration; } \\
\text { Decreased groundwater recharge due to } \\
\text { imperviousness and less infiltration (potentially offset } \\
\text { by presence of pervious areas within urban } \\
\text { infrastructures); } \\
\text { Low flows decreased due to shallow groundwater } \\
\text { pumping but potentially increased due to deep } \\
\text { groundwater pumping; } \\
\text { Water supply and wastewater treatment systems may } \\
\text { increase or decrease low flows depending on cross- } \\
\text { basin transfer. }\end{array}$ \\
\hline $\begin{array}{l}\text { Mean / Total } \\
\text { Flows }\end{array}$ & $\begin{array}{l}\text { Ahn and Merwade, 2014; Bhaskar et al., } \\
\text { 2015; Chen et al., 2017; Claessens et al., } \\
\text { 2006; DeWalle et al., 2000; Diem et al., } \\
\text { 2018; Hollis, 1977; Petchprayoon et al., } \\
\text { 2010; Putro et al., 2016; Rose and Peters, } \\
\text { 2001; Rougé and Cai, 2014; Tetzlaff et al., } \\
\text { 2005 }\end{array}$ & & $\begin{array}{l}\text { Rose and } \\
\text { Peters, 2001; } \\
\text { Wang and } \\
\text { Hejazi, 2011 }\end{array}$ & $\begin{array}{l}\text { In addition to processes affecting low and high flows: } \\
\text { cross-basin transfers of public water and/or sewered } \\
\text { water that may either increase or decrease mean flow. }\end{array}$ \\
\hline
\end{tabular}


25 It appears from Table 1 that diverse impacts were reported depending on the flow 26 characteristics investigated. While the increase in the peak streamflow of flood events is

27 supported by both empirical and modeling studies, the amount of change in high flows is 28 highly variable among studies. Increased catchment imperviousness reduces soil 29 infiltration and consequently baseflow, which may decrease low flows at the outlet of the 30 catchment (Kauffman et al., 2009). However, other factors might mitigate or emphasize 31 the impact on low flows: reduced evaporation from urban areas compared to other land 32 covers (Rose and Peters, 2001), modifications of soil permeability due to topographic 33 modification and soil compaction (e.g. Hibbs and Sharp, 2012). In addition, discharge 34 from wastewater treatment facilities (e.g. Göbel et al., 2004), inter-basin water transfer 35 (e.g. Barringer et al., 1994) and/or groundwater pumping (e.g. Claessens et al., 2006) 36 often occur on urban catchments and may impact the entire flow range, most particularly 37 low flows. Consequently, there is no consensus on the impact of urbanization on 38 catchment low flows that may either increase or decrease (Bhaskar et al., 2015). The 39 impact of urbanization on mean annual flows is complex as a result of the multiple 40 factors described above. Previous studies point out that mean annual flow is either 41 unimpacted (e.g., Rose and Peters, 2001) or increased (e. g. DeWalle et al., 2000).

\section{$42 \quad$ Relating the hydrological impact on urban landscapes}

43 The imperviousness of the catchment has become a benchmark for urban design and 44 zoning criteria (Arnold and Gibbons, 1996; Schueler et al., 2009). At the catchment scale, 45 imperviousness is often calculated as the area-weighted mean of land-use categories with 46 categorical imperviousness values. Mean catchment imperviousness, also referred to as 47 total imperviousness area (TIA), is often suggested to explain the hydrological impact of 
48 urbanization. Diverse mean catchment imperviousness threshold values above which

49 hydrological characteristics are modified have been put forward. Some authors reported

50 significant effects of urbanization at a very low level (5\%) of imperviousness (Booth and

51 Jackson, 1997; Yang et al., 2010), while others observed very small changes up to $20 \%$

52 (Brun and Band, 2000). This wide range of imperviousness threshold values suggests that

53 the total imperviousness of a catchment cannot explain all of the diversity of the

54 hydrological impacts of urbanization. The total imperviousness area is probably a

55 relevant first-order aggregated measure but might overlook other relevant explanatory

56 factors (Alberti et al., 2007) that mitigate and in some cases offset the impact of increased

57 imperviousness. These factors are diverse and include the location of the impervious area

58 within the catchment (Mejía and Moglen, 2010a), in particular its interconnectedness

59 (Mejía and Moglen, 2010b) and its proximity to the drainage network (Grove et al., 1998;

60 Sheeder et al., 2002) as well as the development of hydraulic structures such as detention

61 basins and natural pathway modifications (Ogden et al., 2011) in addition to the natural

62 geomorphological settings of the catchment such as the catchment area, the hydrographic

63 network drainage density and the presence of aquifers (Konrad et al., 2005). So far, few

64 studies have attempted to empirically quantify the effects of these urban land patterns on

65 hydrological catchment behavior.

\section{$66 \quad 1.4 \quad$ Scope of the paper}

67 The objective of this study was to determine whether general conclusions can be drawn

68 on the impact of urbanization on the flow characteristics at the outlet of urbanized

69 catchments. To this aim, a hydrological model was used to quantify the historical change

70 of streamflow characteristics (mean flow, low flow and high flow) due to urbanization 
71 and distinguish it from the change due to climate variability. Then the change of

72 streamflow characteristics is related to modifications of urban landscape metrics within a

73 regression framework, in order to hierarchize the impacts of land use management. To

74 determine flow changes attributable to land use changes (and not climate variability), we

75 followed in this paper the so-called model residual approach, which was found to give

76 comparable results to the paired catchment approach on a set of 24 urban catchments

77 (Salavati et al., 2016). The present study was conducted on 142 U.S. urban catchments in

78 order to reach general conclusions on several open questions: is there a threshold effect of

79 imperviousness on the impact of urbanization? Is the effect of urbanization common to

80 all catchments? Does urbanization affect low, mean and high flows differently? Does the

81 spatial organization of urban areas play a significant role on the impact of urbanization at

82 the catchment scale?

\section{$83 \quad 2 \quad$ DATA}

\section{$842.1 \quad$ Catchment selection}

85 The catchments studied were selected among the 9067 catchments of the GAGES-II

86 database. A preliminary selection was made according to the following criteria: (i) a

87 relatively large fraction of urban areas compared to the total drainage area of the

88 catchment, (ii) long-term flow measurements and (iii) a relatively small impact of

89 upstream dams. For the first criterion, we used the National Land Cover Database

90 (NLCD, Homer et al., 2015) and considered only the catchments presenting a percentage

91 of areas categorized as developed (sum of classes 21, developed: open space; 22,

92 developed: low intensity; 23, developed medium intensity and 24, developed: high

93 intensity in the NLCD classification) greater than $10 \%$ of the total catchment drainage 
94 area. For the second criterion, we used the hydrometric stations presenting more than 30

95 years of data with at least 10 years of data for the 1940-1975 period and 10 years for the

96 1985-2010 period. For the third criterion, we used the mean annual volume of water

97 stored in the dams collected in the GAGES-II database. We converted this volume into a

98 mean annual runoff using the catchment area and we divided the runoff by the mean

99 annual runoff. Finally, we considered that a ratio below 0.1 leads to a relatively small

100 impact of dams over the catchment behavior. Based on these criteria, 430 catchments

101 were selected for the analysis but further selection among this set of 430 catchments

102 were made on the basis of the evolution of urbanization during the flow record periods

103 (see Section 3.2).

$104 \quad 2.2$ Hydroclimatic data

105 Daily precipitation and air temperature data for each catchment were gathered from the 106 database proposed by Livneh et al. (2013). They produced gridded meteorological 107 variables (spatial resolution, $1 / 16^{\circ}$ ) interpolated from ground-based measurements. This 108 dataset was created by incorporating daily observations of maximum and minimum 109 temperature as well as accumulated precipitation from National Weather Service

110 Cooperative Observer stations across the United States for the 1915-2011 period. Daily

111 potential evaporation values were estimated from air temperature data of the gridded data

112 set using the equation proposed by Oudin et al. (2005).

\section{$113 \quad 2.3 \quad$ Historical urbanization data}

114 It was necessary to verify if the urban fraction had indeed evolved significantly over the

115 flow record period. To this aim, we used the housing density (HD) maps at a 90-m 116 resolution developed by Theobald (2005) as a proxy of urban land cover. This allows 
117 estimating long-term changes in urban areas since HD maps were available from 1940 to

118 2010, every 10 years, while NLCD provides only more recent maps (for the years 1992,

119 2001, 2006 and 2011). We considered that urban areas were defined by HD above 145

120 units per $\mathrm{km}^{2}$ (Table 2), which is higher than the threshold used by Theobald ( 25 units per

$121 \mathrm{~km}^{2}$ ) while showing better agreement with NLCD developed area classes. The HD data

122 were reclassified to estimate mean catchment imperviousness (TIA) for each catchment

123 and each decade. The rules of classification (Table 2) were reconsidered from previous

124 studies (Bierwagen et al., 2010; Theobald et al., 2009) to reach better agreement with

125 NLCD impervious surface estimates (Xian et al., 2011), considered as the land cover

126 benchmark. The limitation of estimating urban areas and imperviousness from HD data is

127 that areas of predominately commercial or industrial land use often have high 128 imperviousness but low HD. However, this land use class is present in the HD maps 129 (Urban/Built-up class) and we considered a 90\% corresponding categorical value of 130 imperviousness.

131 Table 2: Reclassification of housing density data to estimate urban areas and imperviousness

\begin{tabular}{cccc}
\hline $\begin{array}{c}\text { Housing density (units } \\
\text { per km²) }\end{array}$ & $\begin{array}{c}\text { Original land cover } \\
\text { classification } \\
\text { (Theobald, 2005) }\end{array}$ & $\begin{array}{c}\text { Urban / nonurban } \\
\text { classification used in } \\
\text { this study }\end{array}$ & Imperviousness (\%) \\
\hline 0 & Undeveloped & Nonurban & 0.0 \\
$<3$ & Rural I & Nonurban & 0.3 \\
{$[3,5]$} & Rural I & Nonurban & 0.6 \\
{$[5,6]$} & Rural I & Nonurban & 0.7 \\
{$[6,8]$} & Rural II & Nonurban & 0.9 \\
{$[8,12]$} & Rural II & Nonurban & 1.1 \\
{$[12,25]$} & Rural II & Nonurban & 1.7 \\
{$[25,145]$} & Exurban/urban & Nonurban & 8.0 \\
{$[145,412]$} & Exurban/urban & Urban & 18.7 \\
$>412$ & Exurban/urban & Urban & 46.3 \\
- & Urban/Built-up & Urban & 90.0 \\
\hline
\end{tabular}


133 As mentioned in the introduction, urbanization often comes along the settings of sewer

134 systems and wastewater treatment facilities that are likely to impact significantly the river

135 flow regime. Unfortunately, no historical nation-wide information exists on rain water

136 sewer system and water treatment facilities while this information should be particularly

137 complementary to imperviousness in an urban context. In this study, we used the density

138 of major Water Treatment Facilities (WTFs) extracted from the GAGE II database for the

139 year 2006. This metric is used along other landscape patterns as an explanatory variable

140 of estimated flow changes.

\section{METHODS}

\section{$142 \quad 3.1 \quad$ Urban landscape patterns considered}

143 Based on reclassified HD maps, we extracted several indicators of urbanization patterns

144 for each decade to analyze the hydrological impact beyond the usual TIA estimate. Table

1453 provides a brief description of these indicators: F.URB and TIA are basic urbanization

146 descriptors, describing only the extent and density of urbanization over the catchment;

147 SI.URB and SI.NURB are landscape fragmentation indices aimed at characterizing the

148 intrinsic structuring of urban areas within the catchment; RDIST.NET, RDIST.OUT and

149 IMP.100 (distribution of the imperviousness of areas in a 100-m buffer area from the

150 hydrographic network) aim at characterizing the location of urban areas within the

151 catchment, in particular their proximity to the drainage network and/or the outlet. All

152 these variables depend on the resolution of the data used. Since HD data are at a 90-m

153 resolution, landscape structuring metrics such as the shape indexes will not take into

154 account small parks and private gardens but they will provide an overview of urban and

155 suburban areas over the catchment. For the metrics related to the hydrographic network 
156 (RDIST.NET and IMP.100), we used the high-resolution National Hydrography Dataset 157 (NHD) and considered only stream rivers flagged as perennial or intermittent, i.e., 158 omitting ephemeral rivers. For some catchments the hydrographic network had been 159 largely modified by urbanization, and historic data are difficult to obtain at this 160 resolution. Consequently, artificial network data, pipelines and ditches that may be 161 identified by the NHD database were not considered in the RDIST.NET and IMP.100 162 estimation. 
Table 3: Urban catchment characteristics used to analyze the different urbanization patterns

over the catchment set

\begin{tabular}{|c|c|c|c|c|}
\hline Notation & Index name & Computation & Class & Interpretation \\
\hline F.URB & $\begin{array}{l}\text { Fraction of urban } \\
\text { areas over } \\
\text { catchment } \\
\text { drainage area }\end{array}$ & $\begin{array}{l}F . U R B \\
=\frac{S . U R B}{S . U R B+S . N U R B} \\
\text { S.URB and S.NURB } \\
\text { correspond to total urban } \\
\text { area }\left(\mathrm{km}^{2}\right) \text { and nonurban } \\
\text { area }\left(\mathrm{km}^{2}\right), \text { respectively }\end{array}$ & $\begin{array}{l}\text { Urban } \\
\text { density }\end{array}$ & $\begin{array}{l}\text { Higher values } \\
\text { mean more } \\
\text { urban areas }\end{array}$ \\
\hline TIA & $\begin{array}{l}\text { Mean catchment } \\
\text { imperviousness }\end{array}$ & $\begin{array}{l}\text { Area-weighted mean of } \\
\text { imperviousness land use } \\
\text { over the catchment area }\end{array}$ & $\begin{array}{l}\text { Urban } \\
\text { density }\end{array}$ & $\begin{array}{c}\text { Higher values } \\
\text { mean higher } \\
\text { imperviousness }\end{array}$ \\
\hline SI.URB & $\begin{array}{c}\text { Shape index of } \\
\text { urban areas }\end{array}$ & $\begin{array}{c}\text { SI.URB }=\frac{\sum P . U R B}{\sqrt{S . U R B}} \\
\text { P.URB corresponds to the } \\
\text { sum of the perimeters of } \\
\text { urban areas }\end{array}$ & $\begin{array}{l}\text { Landscape } \\
\text { structuring }\end{array}$ & $\begin{array}{l}\text { Higher values } \\
\text { mean greater } \\
\text { fragmentation } \\
\text { of urban area }\end{array}$ \\
\hline SI.NURB & $\begin{array}{l}\text { Shape index of } \\
\text { nonurban areas }\end{array}$ & $\begin{array}{l}\text { SI.NURB }=\frac{\sum P . N U R B}{\sqrt{S . N U R B}} \\
\text { P.NURB corresponds to the } \\
\text { sum of the perimeters of } \\
\text { urban areas }\end{array}$ & $\begin{array}{l}\text { Landscape } \\
\text { structuring }\end{array}$ & $\begin{array}{l}\text { Higher values } \\
\text { mean greater } \\
\text { fragmentation } \\
\text { of nonurban } \\
\text { areas }\end{array}$ \\
\hline RDIST.NET & $\begin{array}{l}\text { Ratio of distance } \\
\text { of urban areas to } \\
\text { hydrographic } \\
\text { network }\end{array}$ & $\begin{array}{l}\text { Mean distance of urban } \\
\text { pixels to hydrographic } \\
\text { network divided by the } \\
\text { mean distance of all } \\
\text { catchment pixels to } \\
\text { hydrographic network }\end{array}$ & $\begin{array}{l}\text { Proximity to } \\
\text { hydrographic } \\
\text { network }\end{array}$ & $\begin{array}{l}\text { Higher values } \\
\text { mean urban } \\
\text { areas relatively } \\
\text { far from } \\
\text { hydrographic } \\
\text { network }\end{array}$ \\
\hline RDIST.OUT & $\begin{array}{l}\text { Ratio of distance } \\
\text { of urban areas to } \\
\text { catchment outlet }\end{array}$ & $\begin{array}{l}\text { Mean distance of urban } \\
\text { pixels to catchment outlet } \\
\text { divided by the mean } \\
\text { distance of all catchment } \\
\text { pixels to catchment outlet }\end{array}$ & $\begin{array}{l}\text { Proximity to } \\
\text { catchment } \\
\text { outlet }\end{array}$ & $\begin{array}{l}\text { Higher values } \\
\text { mean urban } \\
\text { areas relatively } \\
\text { far from } \\
\text { catchment } \\
\text { outlet }\end{array}$ \\
\hline IMP.100 & $\begin{array}{l}\text { Mean } \\
\text { imperviousness of } \\
\text { river corridors }\end{array}$ & $\begin{array}{c}\text { Weighted mean of } \\
\text { imperviousness land use in } \\
\text { the } 100 \text {-m riparian buffer } \\
\text { zone }\end{array}$ & $\begin{array}{l}\text { Proximity to } \\
\text { hydrographic } \\
\text { network }\end{array}$ & $\begin{array}{l}\text { Higher values } \\
\text { mean high } \\
\text { imperviousness } \\
\text { of river } \\
\text { corridors }\end{array}$ \\
\hline
\end{tabular}



modeling

168 In this study, we applied the model residual approach to quantify the historical impact of

169 urbanization on different flow components (Kuczera et al., 1993; Seibert and McDonnell,

170 2010). The model residual approach is a widely used approach to determine the impact of

171 land use change on hydrology (see e.g. Li et al., 2012). In the context of urbanization, it

172 was compared to the paired catchment approach and both approaches were in general in

173 good agreements (Salavati et al., 2016). The model residual approach basically consists

174 in calibrating a rainfall-runoff model on a time period before a land use change and

175 simulating flow with this set of calibrated parameters on the time period after land use

176 changes. Analysis of the model residual for the time period after land use changes allows

177 assessing the impact of land use change on streamflow at the outlet of the catchment. The

178 main advantage of the model residual approach is that it allows separating and

179 quantifying the effects of land use change and climate variability/climate change,

180 provided that the calibration of the model for the period before land use change is robust.

181 To apply the model residual approach, we followed the following steps for each

182 catchment: (i) determination of a preurbanization period and a posturbanization period;

183 (ii) calibration of the hydrological model on the preurbanization period, (iii) simulation of

184 streamflow on the posturbanization period using the parameter set obtained in calibration

185 on the preurbanization period, (iv) quantification of flow changes. Each of these steps are

186 detailed hereafter.

187 The preurbanization period was defined as the first 15 years of the streamflow record 188 period while the last 10 years of the streamflow record period were used as the 
189 posturbanization period. The record lengths of these subperiods were chosen since they 190 allow to reach a reasonable trade-off between two objectives: (i) the periods needed to be

191 long enough to provide robust calibration of model parameters for the preurbanization 192 period and significant simulation results for the posturbanization period and (ii) the 193 periods needed to be short enough so that limited land use changes occurred during these 194 two subperiods while important urbanization gradients existed between preurbanization 195 and posturbanization periods. The stationarity of the preurbanization period was assessed 196 in terms of both hydrological model parameter values and urbanization extent. Besides, 197 we restricted the analysis on the catchments for which mean imperviousness had 198 increased by more than $5 \%$ between the preurbanization period and the posturbanization 199 period.

200 The daily rainfall-runoff model with four parameters, GR4J (Perrin et al., 2003), coupled 201 with the CemaNeige snow model (Valéry et al., 2014a, 2014b), was calibrated on the 202 preurbanization period. The association of the GR4J model with a snow module (Figure 203 1) was necessary since the influence of snow accumulation and snowmelt is not 204 negligible on many of the catchments studied. 


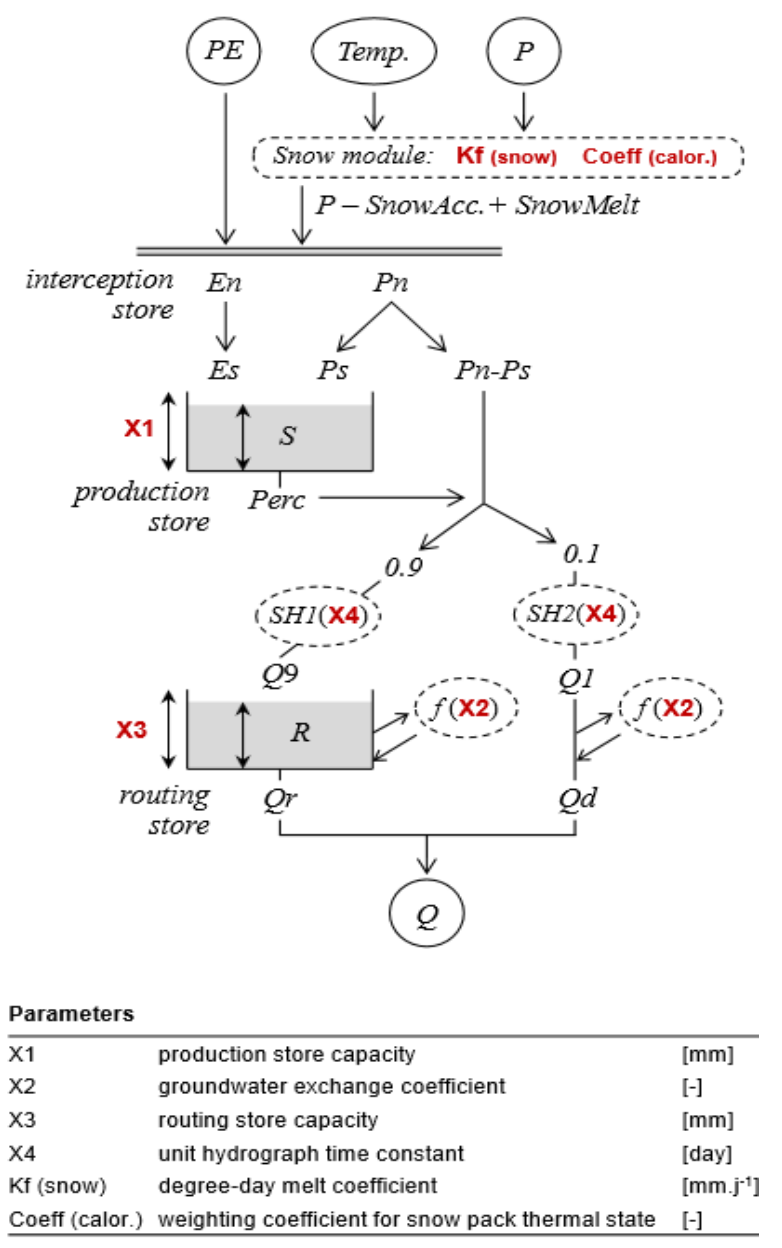

207 Figure 1: Structure of the GR4J rainfall-runoff model used (Perrin et al., 2003) coupled with 208 CemaNeige (Valéry et al., 2014a, 2014b).

209 The model calibration was based on a local search algorithm including a steepest descent

210 variable as used by Edijatno et al. (1999), and the objective function was the Kling-

211 Gupta efficiency criterion (Gupta et al., 2009) applied to root-squared streamflow.

212 Then streamflow for the record period was simulated using the set of parameters

213 calibrated on the preurbanization period (the first 15 years of the record period).

214 Therefore, the simulated discharge is likely to represent the discharge that would have

215 occurred in the urban catchment if urbanization had not expanded. Thus, the differences 
216 between the simulated and observed discharges for the posturbanization period (the last

21710 years of the record period) are attributed to the effect of urbanization change on the

218 hydrologic response.

219 Three flow characteristics were analyzed in this study. The mean annual flow (QMA) 220 allows investigating the impact of urbanization on the catchment's water balance. Annual 221 low flow (Q05) and high flow (Q95) characteristics were also computed to investigate the 222 impact of urbanization on extreme flow values. Q05 and Q95 represent the daily 223 discharges that were exceeded during $95 \%$ and $5 \%$ of each year of the record period, 224 respectively. To quantify the changes for the three annual flow components, we 225 computed the change based on differences between the regression equations obtained for 226 pre- and posturbanization periods at a specific flow value corresponding to the mean of 227 the observed flow characteristic over the whole record period (Salavati et al., 2016). The 228 equation used to determine the absolute flow change takes the general form of Eq. (1):

$$
\text { Eq. (1) } \quad \mathrm{CQ}=\mathrm{E}_{P O S T}\left(\left.Q_{o b s}\right|_{Q_{s i m}=\overline{Q_{o b s}}}\right)-\mathrm{E}_{P R E}\left(\left.Q_{o b s}\right|_{Q_{s i m}=\overline{Q_{o b s}}}\right)
$$

229 Where CQ is the absolute flow change for a given flow characteristic (Q05, Q95 or 230 QMA), $\mathrm{E}_{P O S T}$ and $\mathrm{E}_{P R E}$ are the linear regressed models between the annual observed 231 flow characteristic (the dependent variable) and simulated flow characteristic (the 232 explanatory variable) for the preurbanization period and the posturbanization period 233 respectively and $\overline{Q_{o b s}}$ is the mean of observed annual flow characteristics over the entire 234 record period. Consequently, $\mathrm{E}_{P O S T}\left(\left.Q_{o b s}\right|_{Q_{s i m}=\overline{Q_{o b s}}}\right)$ and $\mathrm{E}_{P R E}\left(\left.Q_{o b s}\right|_{Q_{s i m}=\overline{Q_{o b s}}}\right)$ represent 235 the regressed values of Qobs for the specific value of $\overline{Q_{o b s}}$ using the linear models $\mathrm{E}_{P O S T}$ 236 and $\mathrm{E}_{P R E}$ respectively. 
237 Since the hydroclimatic settings of the catchments are quite diverse, relative changes are

238 shown instead of absolute changes, by dividing the absolute change by the mean annual

239 flow characteristics for the preurbanization period. As the mean annual Q05 can be very

240 close to zero for some catchments, the relative Q05 change is expressed as a percentage

241 of mean annual flow, i.e., the absolute Q05 change is divided by the mean annual flow of

242 the preurbanization period.

\subsection{Relating the hydrological impact of urbanization to urban landscape patterns}

245 To relate flow changes to urban landscape change, we considered absolute differences

246 between the posturbanization period and preurbanization period for all urban landscape

247 variables, except RDIST.NET and RDIST.OUT for which only the new urban pixels

248 were used to compute the metric. Therefore, the notations used hereafter to describe the

249 evolution of urban landscape patterns are d.F.URB, d.TIA, d.SI.URB, d.SI.NURB,

250 RDIST.NET, RDIST.OUT and d.IMP.100. For RDIST.NET and RDIST.OUT, the

251 differences between the metrics for the pre- and posturbanization periods were biased by

252 the differences in terms of urban extent. To focus on the locations of urban sprawl

253 between the two periods, we computed RDIST.NET and RDIST.OUT by considering

254 only the areas that were changed from rural to urban between the two periods. Besides,

255 the density of major wastewater treatment facilities for the year 2006 was used as a

256 complementary explanatory variable.

257 For each of the three flow variables Q05, Q95 and QMA, separate analyses were 258 performed. Streamflow change detections were calculated for each urban catchment for 259 the pre- and posturbanization record period. From the set of independent variables, 260 backward stepwise regression was used to identify the best linear models, using the 
Bayesian information criterion (BIC), which was preferred to the Akaike information criterion (AIC) since it tends to identify less parametrized models. The regression model was fit between the dependent variables (the change of one of the three flow components)

264 and the changes of the selected urban catchment characteristics as the independent 265 variables.

266 Regression equations take the general form of Eq. (2):

$$
\text { Eq. (2) } \quad C Q_{i}=\beta_{0}+\beta_{1} X_{1}^{i}+\beta_{2} X_{2}^{i}+\cdots+\beta_{n} X_{n}^{i}
$$

267 where $C Q_{\mathrm{i}}$ is the streamflow change for the $\mathrm{i}$-th catchment, $X_{j}^{i}$ is the change of the $\mathrm{j}$-th

268 urbanization catchment characteristic of the $\mathrm{i}$-th catchment and $\beta_{\mathrm{j}}$ are the linear model 269 coefficients. Since three flow characteristics were analyzed, three regression equations 270 were obtained. From the selected models, we performed hierarchical partitioning to 271 assess the relative contribution of each predictor within the $\mathrm{R}$ environment software, 272 using the hier.part package (Walsh and Mac Nally, 2003).

\section{$273 \quad 4 \quad$ RESUlts}

\section{$274 \quad 4.1 \quad$ Catchment urbanization patterns}

275 To assess the potential of using HD data as a proxy for imperviousness, we estimated the 276 urban fraction and catchment imperviousness (i.e., TIA) using the lookup Table 2 for 277 each catchment for the year 2010 and compared it to data given by NLCD database for 278 the year 2011 since NLCD is considered as the reference database. Figure 2 shows that 279 HD data satisfactorily estimated the fraction of urban areas and mean catchment 280 imperviousness. The fraction of urban areas estimated by HD is generally underestimated 281 compared to the NLCD database, while mean catchment imperviousness is slightly 282 overestimated for those catchments presenting low TIA values. Overall, the correlation 
coefficients for both the fraction of urban areas and mean catchment imperviousness are

284 above 0.96 , corroborating the results of previous studies that used HD data to derive 285 urban fractions (Over et al., 2016). The slight biases observed are probably due to the 286 choice of the classes of the original HD dataset (Table 2) and more classes around the 287 urban/nonurban threshold and in the upper values of HD would probably provide better 288 agreement between HD estimates and NLCD products.
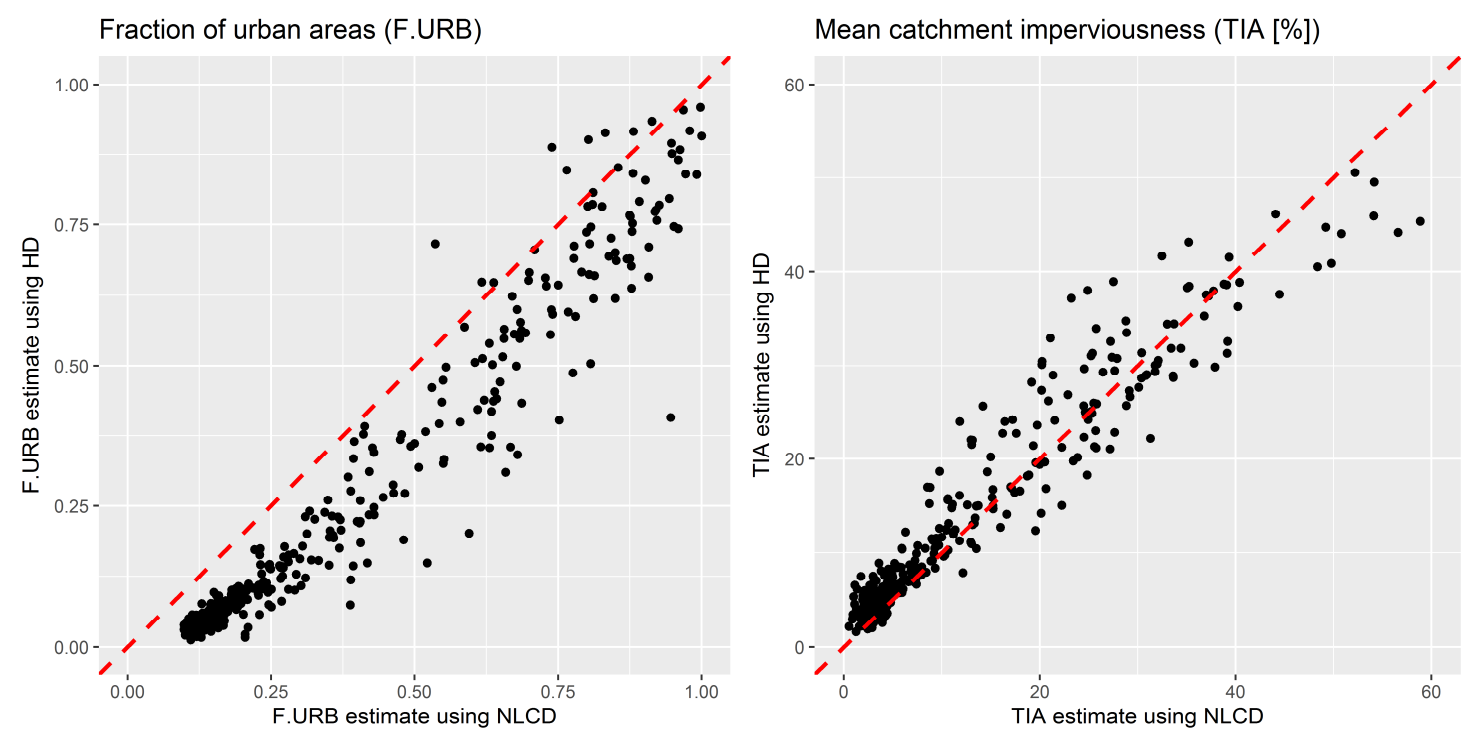

290 Figure 2: Fraction of urban areas and catchment imperviousness from NLCD database and HD maps on the 430 urban catchments. The NLCD data for urban areas corresponds to the sum of the developed area classes (21-24) for the year 2011, and the catchment imperviousness corresponds to the 2011 imperviousness map; HD estimates were derived from the $2010 \mathrm{HD}$

294 map using the reclassification proposed in Table 2.

295 To investigate whether the urban fraction had evolved significantly between the 296 preurbanization period and the posturbanization period and among the preurbanization 297 period, we used the HD maps that were available from 1940 to 2010, every 10 years. For 298 each catchment, we used three HD maps representative of the preurbanization and the 299 posturbanization periods: a map characterizing the beginning of the preurbanization 
300 period (for this map, we selected the closest decade to the beginning of the 301 preurbanization period), a map characterizing the end of the preurbanization period (for 302 this map, we selected the closest decade to the end of the preurbanization period) and a 303 map characterizing the posturbanization period (for this map, we selected the closest 304 decade to the end of the posturbanization period). The first two maps are used to 305 investigate possible evolution of urbanization during the preurbanization period and the 306 first and third maps are used to assess the evolution of urbanization between the 307 preurbanization period and the posturbanization period. The urban catchment 308 characteristics listed in were calculated for these representative maps and TIA evolution 309 was analyzed in order to check whether the selected catchments changed significantly in 310 terms of urbanization over the flow record period and within the preurbanization period.

311 It is noteworthy that TIA evolution was computed as the absolute difference between TIA 312 for the posturbanization period and TIA for the preurbanization period, i.e. a $5 \%$ increase 313 of TIA between the two periods means that TIA had increased by $5 \%$ of the catchment 314 area. Figure 3 notably shows that for many catchments, the increase of mean catchment 315 imperviousness over the flow record period is low. The urban catchments were initially 316 selected based on the fraction of urban areas given by NLCD for the year 2011 and many 317 of the catchments selected were already urbanized at the beginning of the flow record 318 period. Only 209 catchments presented an evolution of TIA greater than 5\% between the 319 preurbanization period and the posturbanization period. Besides, the evolution of TIA 320 during the preurbanization period is generally low but greater than $5 \%$ for 50 catchments.

321 Since we aimed at relating the hydrological changes to the urbanization patterns over the 322 catchment set, we decided to focus on the catchments for which mean imperviousness 
323 had increased by more than $5 \%$ between the preurbanization and posturbanization periods

324 while presenting low (less than 5\%) evolution of TIA within the preurbanization period.

325 This leads to a reduction of the catchment set from 430 to 142 catchments (see location 326 on Figure 4) with drainage areas ranging from 10 to $7000 \mathrm{~km}^{2}$ and a median value of 150 $327 \mathrm{~km}^{2}$.

328

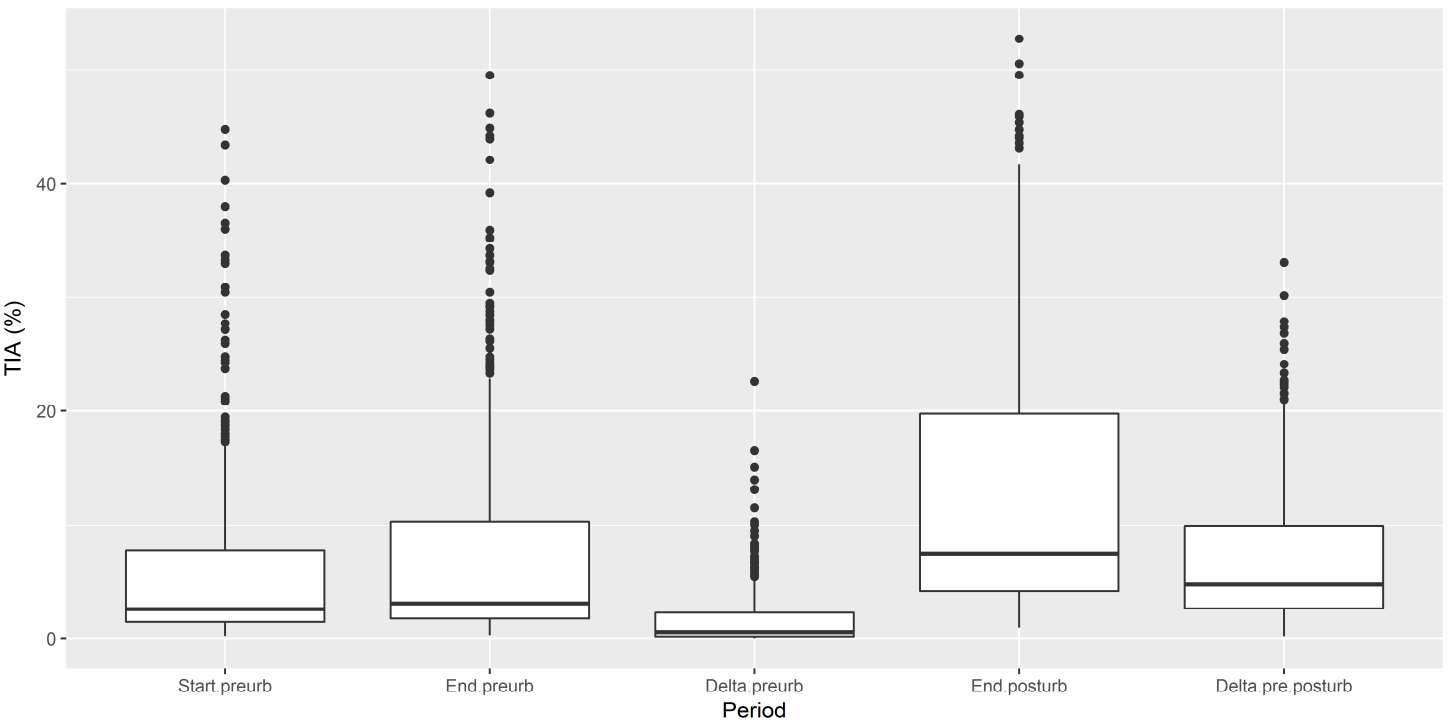

Figure 3: Distribution of the mean catchment imperviousness for the pre- and posturbanization periods and TIA evolutions.

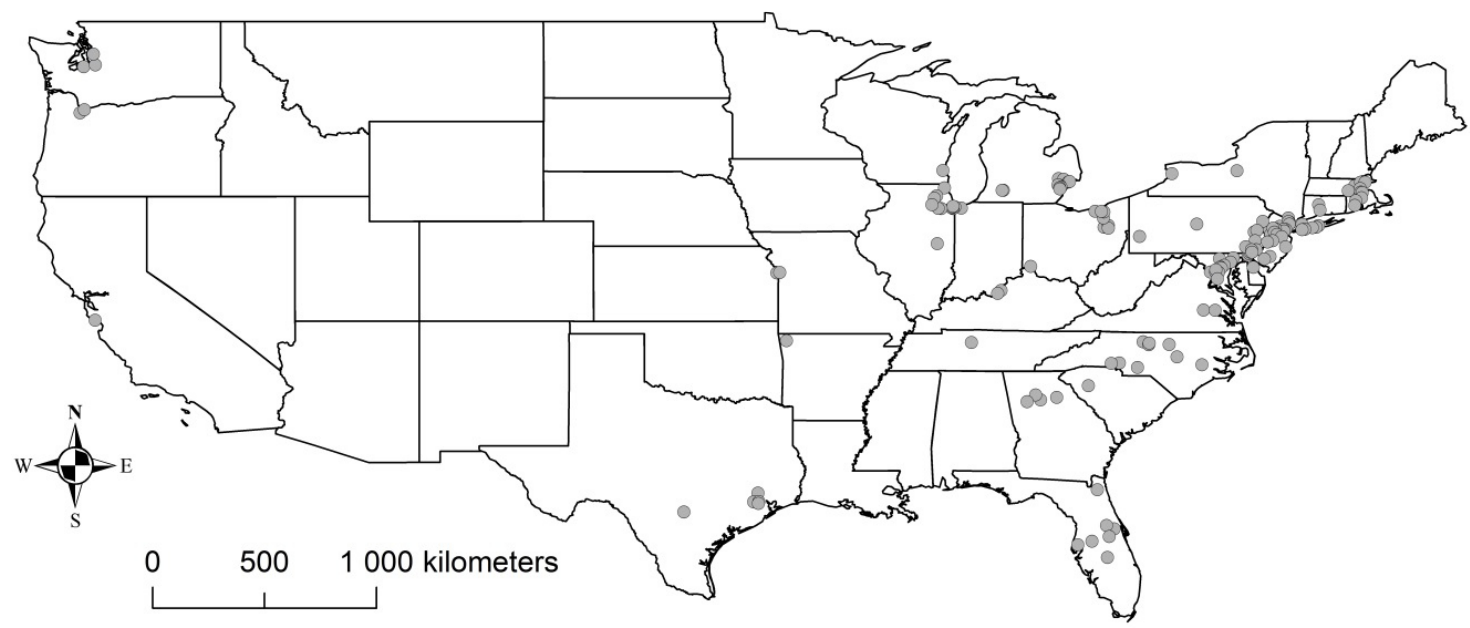

332 Figure 4: Location of the 142 urban catchments studied. 
333 The distributions of the seven urban catchment characteristics listed in Table 3 are shown

334 in Figure 5 for the 142 selected catchments. The distributions of the fraction of urban

335 areas (F.URB) and the mean catchment imperviousness (TIA) are relatively similar,

336 which is expected since the two metrics are highly correlated with each other. The

337 distributions of both F.URB and TIA are also similar to the distribution of the

338 imperviousness of areas in a 100-m buffer area from the hydrographic network

339 (IMP.100), meaning that urbanization led to increased imperviousness relatively

340 homogeneously at the catchment scale and in the vicinity of hydrographic network.

341 Fragmentation of the nonurban landscape (SI.NURB) is generally increased, but some

342 catchments present decreased nonurban fragmentation. Fragmentation of the urban

343 landscape (SI.URB) is either increased or decreased depending on the catchments

344 considered, meaning that urban development can be either concentrated or scattered over

345 the catchment area. This also stems from urban sprawl taking place in the vicinity of

346 already urban areas for some catchments while for other catchments, new urban areas

347 disconnected from urban areas already present emerged. The distributions of the distance

348 ratio of urban areas to the hydrographic network (RDIST.NET) shows that urban areas

349 are not necessarily located in the vicinity of the hydrographic network (RDIST.NET

350 generally above 1) and for a majority of the catchments, new urban areas are relatively

351 far from the hydrographic network (delta of RDIST.NET above 1 for $70 \%$ of the 142

352 catchments). The distributions of the distance ratio of urban areas to catchment outlets

353 (RDIST.OUT) show that urban areas are not preferentially located close to or far from

354 the catchment outlet, but a wide variety of situations exists. 
355 To conclude on these urbanization characteristics, the set of 142 catchments present a 356 wide variety of urbanization patterns in terms of quantity and spatial structuring within 357 the catchment area. This diversity offers the opportunity to analyze the change of 358 streamflow with regards to these diverse urbanization characteristics.
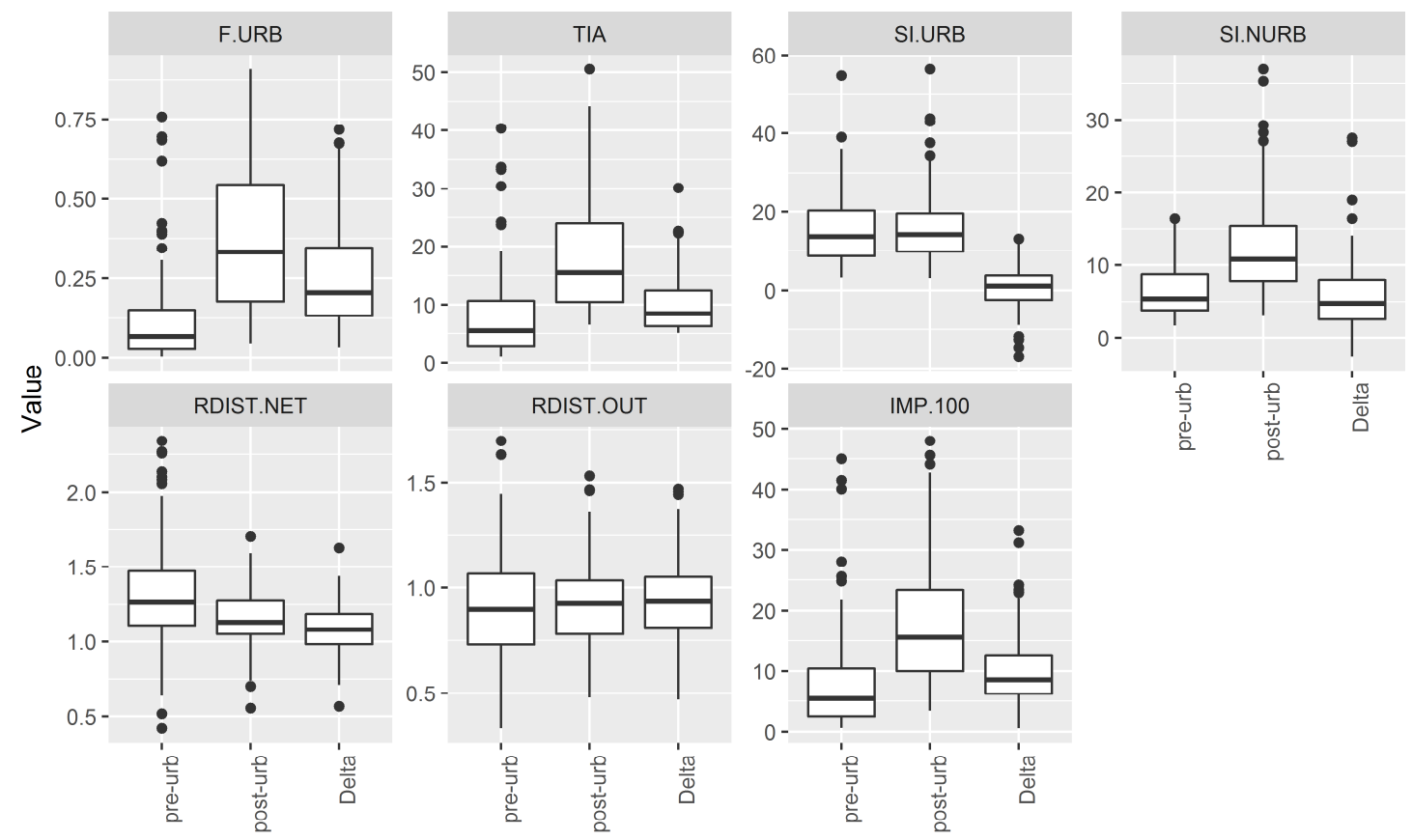

Periods

360 Figure 5: Catchment urbanization patterns for the preurbanization and posturbanization

361 periods. The boxplots represent the distribution of the variables over the 142 catchments 362 studied. The bottom and top of the boxes represent the first and third quartiles and the 363 whiskers represent the 1.5 interquartile range.

364 Figure 6 provides an illustration of the diversity of urbanization patterns. For a similar 365 extent of urban areas (from around 5\% of the catchment area in 1940 to around $18 \%$ in 366 2010), urban areas are more fragmented on the Quinnipiac River (shape index SI.URB 21 367 and 23 for 1940 and 2010, respectively) compared to the Whippany River (shape index 368 SI.URB 8 and 11 for 1940 and 2010, respectively). Similarly, nonurban areas are more 369 fragmented on the Quinnipiac River (shape index SI.NURB 6 and 12 for 1940 and 2010, 
371 and 2010, respectively). The differences of these indexes for the posturbanization and

372 preurbanization periods point out that urbanization leads to more fragmented nonurban

373 areas over the Quinnipiac River at Wallingford.
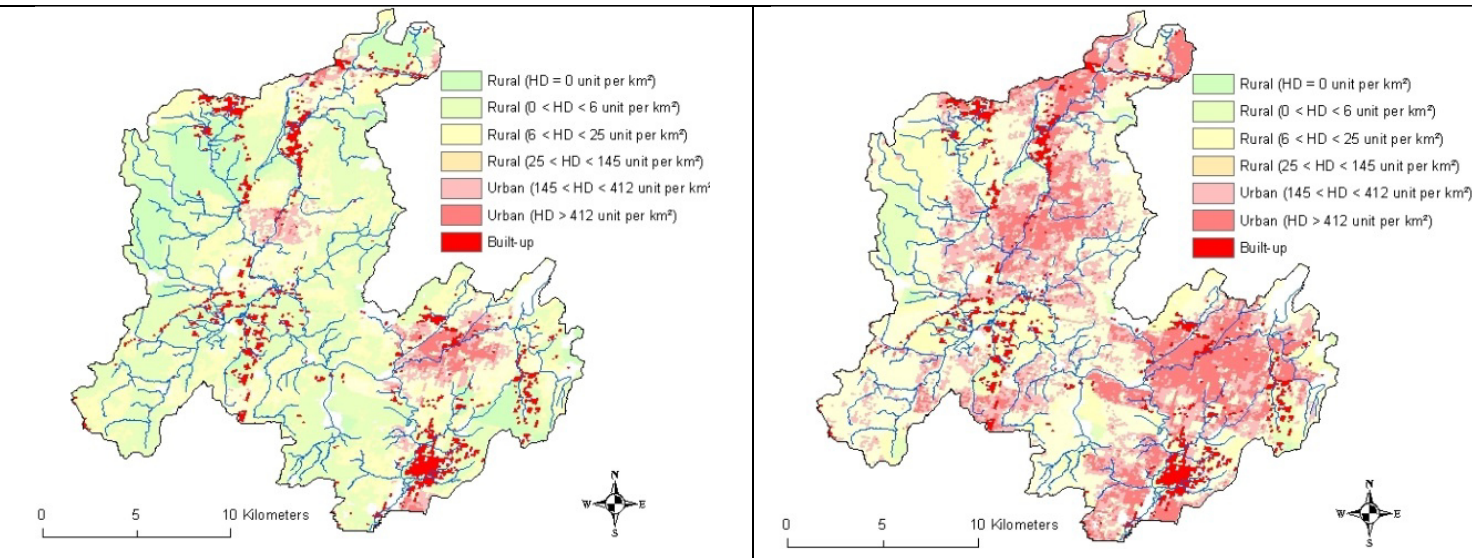

Housing density of the Quinnipiac River at Wallingford in 1940

Housing density of the Quinnipiac River at Wallingford in

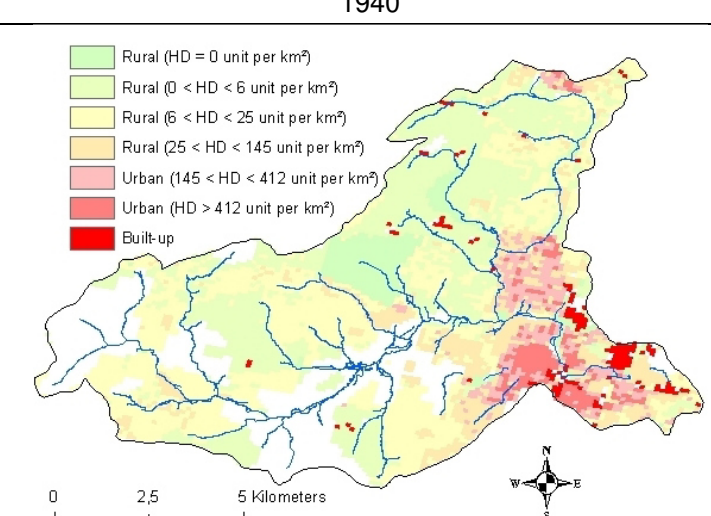

Housing density of the Whippany River at Morristown in 1940

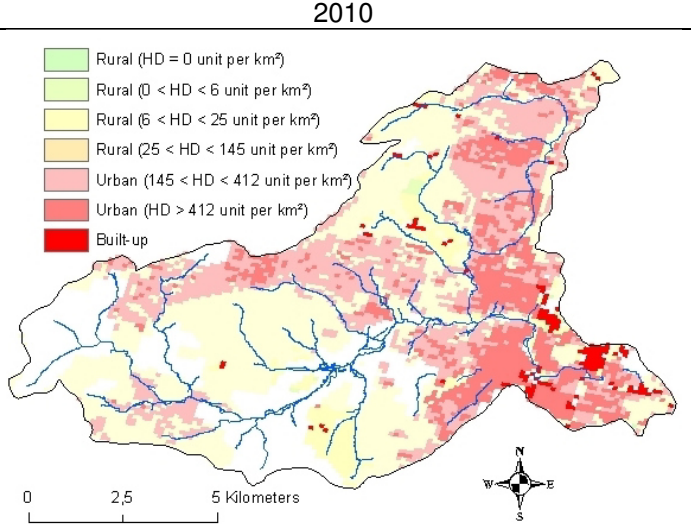

Housing density of the Whippany River at Morristown in 2010

Figure 6: Two contrasted examples of catchment urbanization patterns. For a similar extent of urban area, the Quinnipiac River at Wallingford (top) presents more fragmented urban and nonurban areas than the Whippany River at Morristown (bottom) for which concentrated urban areas are located in the downstream part of the catchment.

379 Since the estimated flow changes are based on the model's ability to simulate the low-

380 urbanization configuration of the catchments, we analyzed the calibration results of the 
381 hydrological model using four criteria. The first criterion is the Kling-Gupta efficiency

382 criterion applied to root-squared streamflow, which is also used as the objective function

383 during the optimization process of the model parameters. The three other criteria aimed at

384 assessing the ability of the model to simulate the three streamflow characteristics (Q05,

385 Q95 and QMA) calculated at the annual time-scale. Since the quantification of the

386 hydrological impact of urbanization is based on the changes of the linear relationships

387 between simulated and observed annual flow characteristics, we used the coefficients of

388 determination $\left(\mathrm{R}^{2}\right)$ of these relationships.

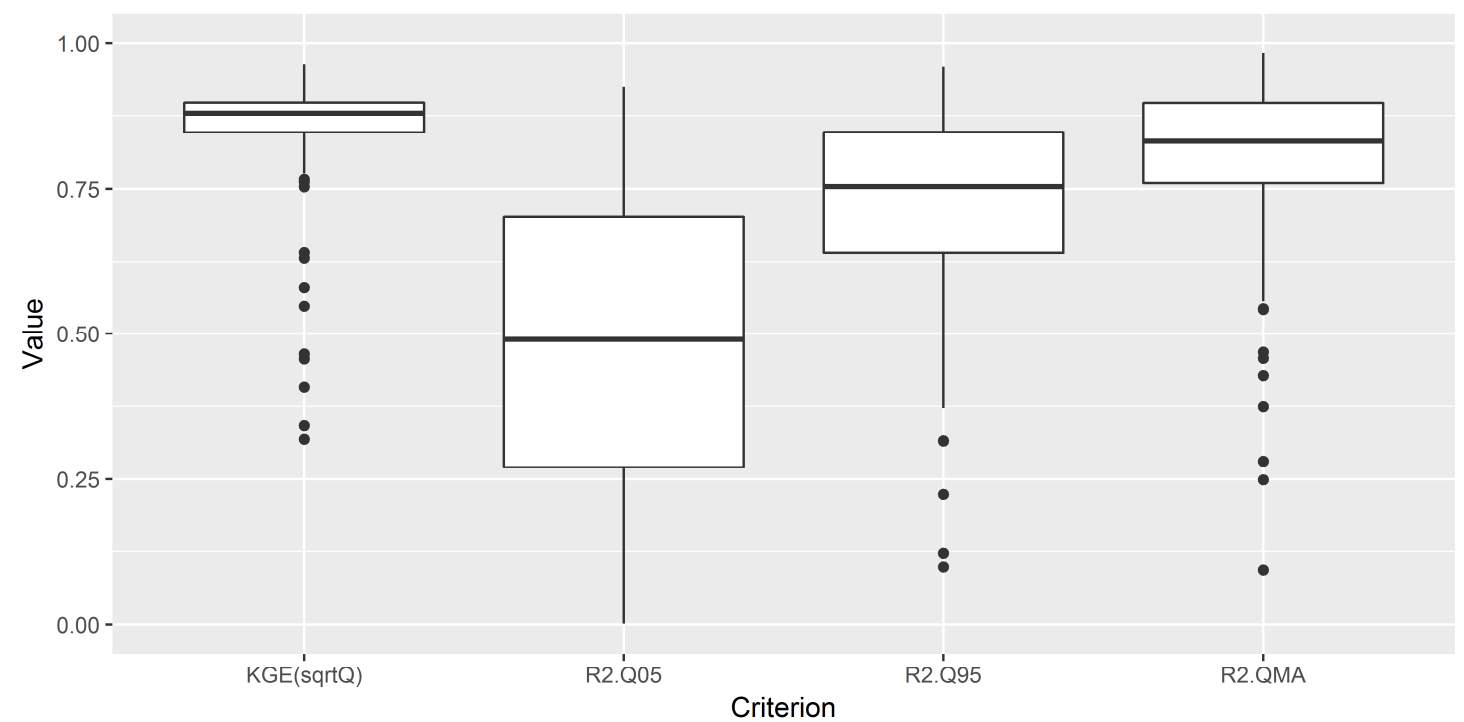

390 Figure 7: Model calibration efficiency over the 142 catchments studied. KGE(sqrtQ) is the

391 Kling-Gupta efficiency criterion on root-squared transformed daily flow, R2.Q05 R2.Q95 and

392 R2.QMA are the coefficients of determination of annual streamflow characteristics. The

393 bottom and top of the boxes represent the first and third quartiles and the whiskers represent

394 the 1.5 interquartile range.

395 Figure 7 shows that daily streamflows are generally well simulated by the hydrological 396 model (75\% of KGE values above 0.84). Mean annual flow values are also well 397 represented (75\% of the R2.QMA above 0.76), while high- and low-flow percentiles are 
398 more difficult to reproduce (75\% of the R2.Q95 above 0.64 and $75 \%$ of R2.Q05 above 399 0.27). One may argue that this results from the choice of the objective function, but using 400 another objective function dedicated to low flows (e.g., KGE on log transformed flows) 401 does not improve R2.Q05 since it mainly reduces the model's bias on low flows while 402 only marginally improving the explained variance of the annual Q05 samples. For the 403 sake of homogeneity of the model simulations, we kept a single objective function for 404 simulating the three streamflow characteristics.

405 The model's low level of efficiency in simulating low flows (and to a lesser extent high 406 flows) is inherent to hydrological model but poses the question of the reliability of model 407 simulations for the calibration period (i.e., the period before urbanization extended) and 408 for the simulation period (i.e., the period after urbanization extended). However, the 409 linear relationships obtained between annual flow characteristics are in general 410 significant at a 0.01 threshold p-value: 107 out of 142 for Q05, 139 out of 142 for Q95 411 and 140 out of 142 for QMA.

412 Another caveat of the model residual approach is the parameter uncertainty issue. To 413 address this issue, we tested the robustness of the model calibration during the 414 preurbanization by applying a split sample test over this period: the model is calibrated 415 on the first seven years and test in validation mode over the last seven years and vice416 versa. Figure 8 compares the model performance for the model calibration and validation 417 periods. The performance is assessed by the objective function used for calibration 418 (Kling-Gupta efficiency criterion on root-squared transformed daily flow). 


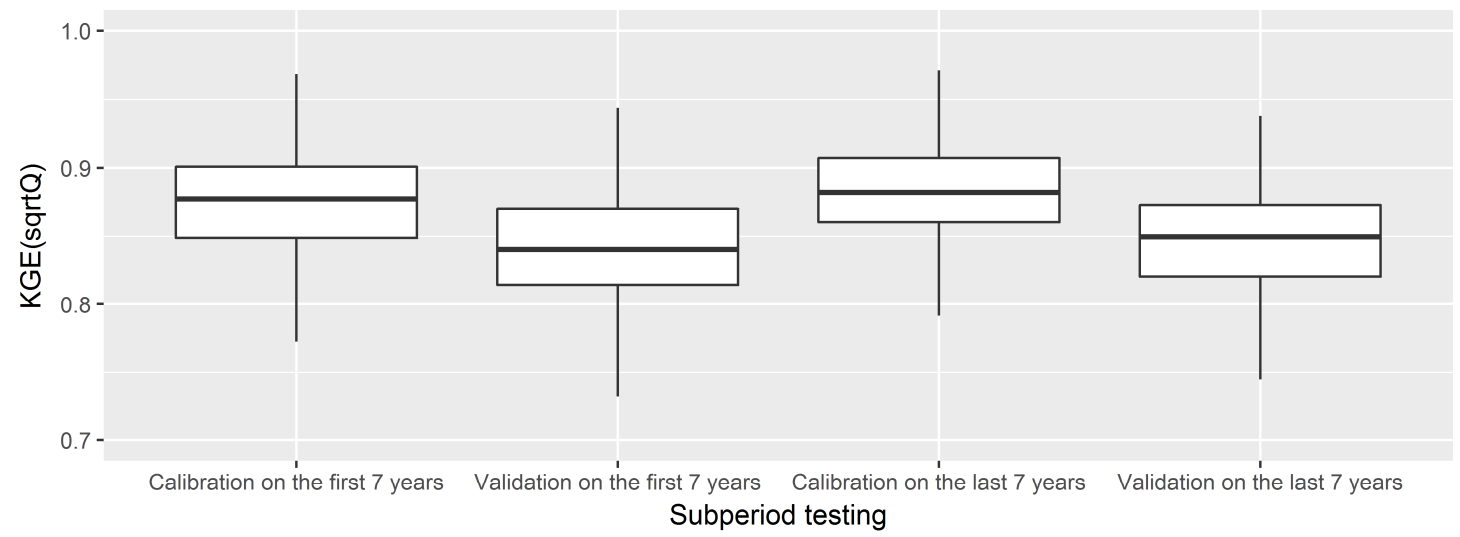

$420 \quad$ Figure 8: Results of the split sample test applied on the preurbanization period for the 142 421 studied catchments. KGE(sqrtQ) is the Kling-Gupta efficiency criterion on root-squared 422 transformed daily flow. The bottom and top of the boxes represent the first and third quartiles 423 and the whiskers represent the 1.5 interquartile range.

424 Median Kling-Gupta efficiency on square-rooted streamflow over the catchment set is 4250.87 and 0.88 during calibration (First and last seven years respectively) and 0.83 and 4260.84 during validation (First and last seven years respectively). The gap between 427 calibration and validation results is relatively small and comparable with other large428 sample studies with this hydrological model (Poncelet et al., 2017). This suggests that 429 model calibration is relatively robust in-between the preurbanization period, making the 430 model residual approach appropriate for our study.

\subsection{Analysis of the hydrological impacts of catchment imperviousness}

434 Figure 9 provides an overview of the relative flow changes estimated over the 142 urban 435 catchments considered, with respect to the total imperviousness increase over the flow record period. The impact of the imperviousness increase is clear for high and mean flow:

437 an increase of TIA in most cases led to an increase of flow, which is, however, diverse 438 over the catchment set. It is noteworthy that a relatively low TIA increase (less than 439 around $10 \%$ ) does not affect the flow characteristics considered. This result corroborates 
440 a number of previous studies pointing out a threshold value of imperviousness above

441 which the hydrological impacts of urbanization become significant. The threshold value

442 reported in the literature is generally between 5 (Booth and Jackson, 1997; Yang et al.,

4432010 ) and 20\% (Brun and Band, 2000), and the 10\% value obtained over the set of 142

444 catchments lies between these reported values.

445 As for the low-flow characteristic, the estimated changes also appear greater for larger

446 TIA increases, but the sign of the changes can be either negative or positive depending on

447 the catchment. This means that the Q05 response to urbanization is complex and the TIA

448 increase might not be the best variable to explain alone the low-flow changes on some

449 catchments.
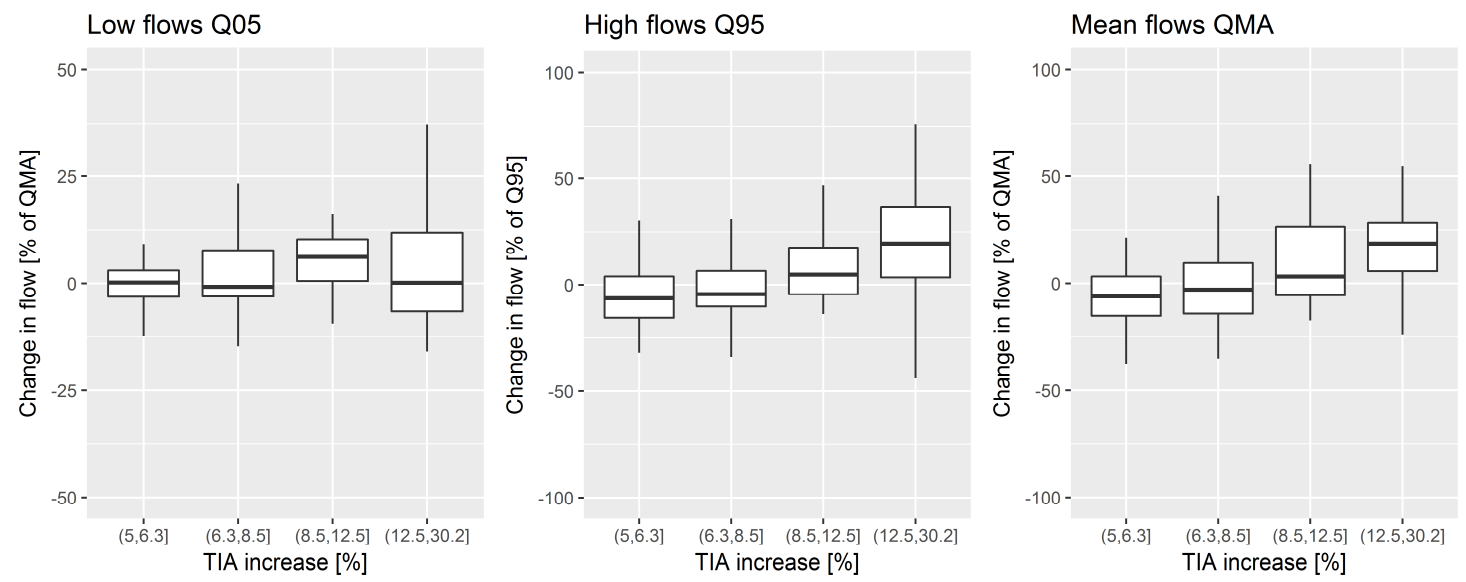

451 Figure 9: Relative changes for low (Q05) high (Q95) and mean (QMA) flow characteristics of 452 the 142 catchments studied. Values are given for four TIA increase classes (5.0-6.3\%, 6.3$453 \quad 8.5 \%, 8.5-12.5 \%, 12.5-30.2 \%)$, each class representing 35-36 catchments.

4.4 Influence of urban landscape patterns on hydrological impacts

455 To shed more light on the landscape patterns affecting most flow characteristics on the

456142 catchments studied, this section relates the relative flow changes to the changes in 457 urban landscape patterns. The explanatory variables tested that were used for the 
458 regression analysis were initially the absolute differences between the preurbanization 459 and posturbanization periods of the metrics presented in Table 3. Since d.F.URB, d.TIA 460 and d.IMP.100 presented a quite high cross correlation (above 0.95), only d.TIA is used 461 hereafter. In addition, we used the density of major facilities WTFs extracted from the 462 GAGE II database, for the year 2006.

463 The hierarchical partitioning (Figure 10) revealed that the density of major WTFs 464 presents the highest independent contribution in low-flow changes (71\%), but also a high 465 contribution in high- and mean-flow changes ( $23 \%$ and $45 \%$, respectively). The increase 466 of mean catchment imperviousness (d.TIA) presents the highest independent contribution 467 to high-flow changes $(40 \%)$ and also has a high contribution to mean-flow changes $468(22 \%)$. The evolution of the fragmentation of urban areas d.SI.URB presents a relatively 469 high contribution to high- and mean-flow changes (28\% and 25\%, respectively). Finally, 470 the metrics characterizing the distance of urban areas from the hydrographic network or 471 catchment outlet present a low contribution to all flow changes. This means either that 472 the location of urban areas has a second-order importance or that the metrics used are not 473 appropriate to describe the connectivity of urban areas to the hydrographic network. 


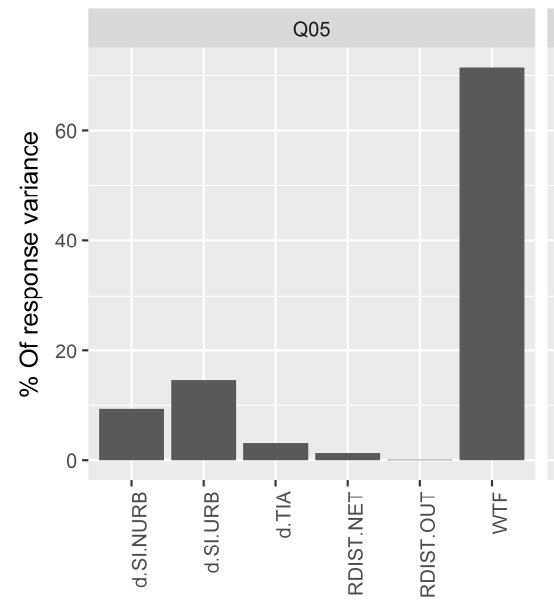

474

475

476

477

478

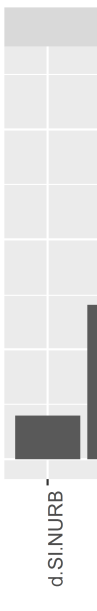

Dependent variables

Q95

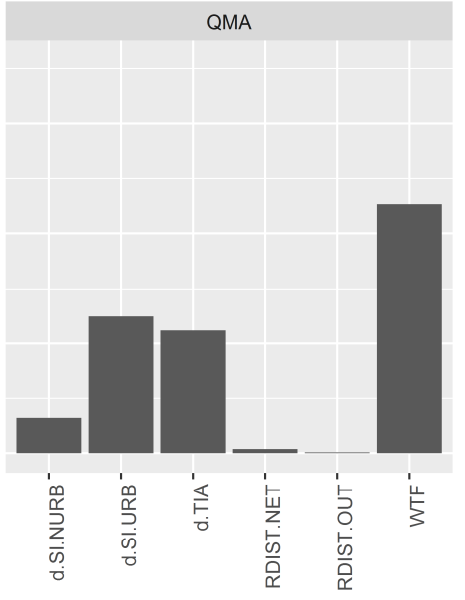

Figure 10: Hierarchical partitioning indicating the relative contribution (\%) of each predictor to the variance explained by the linear models relating changes of flow characteristics and urbanization characteristics over the 142 urban catchments studied

Regression modeling also demonstrated the high influence of wastewater treatment facilities on flow changes (Table 4). The models indicate that a higher number of WTFs, indicating greater density of water treatment facilities, is associated with increased flows. The catchment imperviousness variation (d.TIA) is also selected for all flow characteristics. It demonstrated a positive relationship with high and mean flow, but a negative relationship with low flow. This paradoxical effect of imperviousness on flow changes might be due to increased surface flow and decreased baseflow within the urbanized catchment, even if the presence of WTFs may offset the decreased low flow due to imperviousness for some catchments. Fragmentation metrics were also included in the best linear models. The shape index of urban areas shows a negative relationship with flow change, meaning that more fragmented (or less concentrated) urban landscapes are associated with a lower impact on flow change. Contrary to imperviousness, the variation of fragmentation is homogenously associated with flow changes. Finally, as suggested by the hierarchical analysis shown before, the metrics associated with the proximity of urban 
areas to the hydrographic network are marginally selected. Only the distance of new

493 urban areas is included in the best models for high and mean flow. The negative

494 relationship indicates that a development of urban areas near the catchment outlet (i.e.,

495 shorter distance) is associated with greater flow changes.

Table 4: Results obtained from the stepwise selection procedure. The coefficients displayed in the table are those that were extracted from the best model (through BIC) for each flow characteristic. Stars represents the p-value range ' ${ }^{*} * * *$ ' $<0.001$, ' $* *$ ' $<0.01$, ' $* *$ ' $<0.05$.

\begin{tabular}{|c|c|c|c|c|c|c|c|}
\hline & \multicolumn{6}{|c|}{ Independent variables (Student $t$ variable and p-values) } & \multirow{2}{*}{$\begin{array}{l}\begin{array}{c}\text { Goodness } \\
\text { of fit }\end{array} \\
\begin{array}{c}\text { Adjusted } \\
\text { R }^{2}\end{array}\end{array}$} \\
\hline $\begin{array}{c}\text { Flow } \\
\text { changes }\end{array}$ & d.TIA & d.SI.URB & d.SI.NURB & RDIST.NET & RDIST.OUT & WTF & \\
\hline d.Q05 & $-2.88 * *$ & $-3.78 * * *$ & $2.79 * *$ & - & - & $7.17 * * *$ & 0.387 \\
\hline d.Q95 & $3.82 * * *$ & $-2.49 *$ & - & - & $-2.33 *$ & $3.20 * *$ & 0.327 \\
\hline d.QMA & $3.37 * * *$ & $-3.26 * *$ & - & - & $-2.71 * *$ & $6.46 * * *$ & 0.446 \\
\hline
\end{tabular}

\section{Discussion AND CONCLUSION}

501 This study attempted to draw general conclusions on the hydrological impact of

502 urbanization at the catchment scale. To this aim, the derived methodology is based on a

503 hydrological modeling framework to minimize the flow change attributed to climate

504 variability. The choice of a relatively simple and somewhat parametrized conceptual

505 rainfall-runoff model enabled us to apply the same methodology to a wide range of

506 catchments with several hydroclimatic settings and with diverse levels of urban sprawl.

507 This choice was also warranted because the model is not used to simulate the changes of

508 hydrological processes within the catchment but to simulate the streamflow that would

509 have occurred without urbanization. The results shed new light on several common

510 questions on the impact of urbanization.

511 An imperviousness threshold effect on the impact of urbanization was observed. This

512 threshold reflects an approximately $10 \%$ increase in mean catchment imperviousness 
513 (TIA) and affects the three flow characteristics studied (Q05, Q95 and QMA). This

514 threshold is in agreement with other studies conducted on a more limited number of

515 catchments (e.g. Booth and Jackson, 1997; Yang et al., 2010). However, at this stage it is

516 difficult to conclude definitively on this threshold value. Does the catchment buffer

517 urbanization up to this threshold or does the lack of significant impacts detected below

518 this threshold reflect the undeniable uncertainties related to the hydrological modeling

519 framework? It is more likely that above a $10 \%$ increase in mean catchment

520 imperviousness the hydrological impacts of urbanization overtake the modeling

521 uncertainties.

522 Another question raised in the literature is the common effect of urbanization on flow

523 characteristics among urbanized catchments. The literature generally reports that

524 urbanization increases high flow, which was also observed clearly on the catchments

525 studied. The observation was similar for mean annual flow since a large majority of the

526 urbanized catchment presented positive flow changes. Concerning low flow, the results

527 obtained in this study reflect the diversity of the results reported in previous studies since

528 the catchment set studied shows both increased and decreased low flows. Therefore, the

529 effect of urbanization seems relatively common to all catchments for high and mean

530 flows but highly variable for low flows.

531 Another issue addressed in this study is the role of the spatial organization of urban areas

532 on the hydrological impact of urbanization. Over the landscape patterns analyzed in this

533 study, mean catchment imperviousness (TIA) was indeed a key variable but other

534 relevant metrics can help understand the variability of the impacts of urbanization. It was

535 shown that the fragmentation of urban areas presents a negative relationship with flow 
536 changes, suggesting that the fragmentation of urban areas mitigates the impacts of

537 urbanization. Interestingly, considering several landscape metrics better identifies the role

538 of mean catchment imperviousness since a positive relationship was found for high and

539 mean flow, whereas a negative one was found for low flows, suggesting that all things

540 being equal, increased imperviousness decreases low flows and increases high flows.

541 The prominence of the density of major wastewater treatment facilities in the best linear

542 models raises the issue of compensation of the effects of imperviousness and the

543 development of water treatment facilities. To investigate the sole impact of urban

544 landscape patterns on low flow, it would be interesting to focus on urban catchments with

545 no major water treatment facilities or to take explicitly into account flow from water

546 treatment facilities. Unfortunately, the catchment set used here did not allow this further

547 analysis and a study focusing on a smaller catchment set would probably be more

548 appropriate to obtain the data to perform this analysis. Another hypothesis of this study

549 that was not verified given the large catchment set is that urbanization may be the

550 dominant change over the catchment during the record period. The results obtained

551 suggest that this hypothesis might be valid for a majority of catchments, but a more

552 detailed assessment of historical changes over the catchments in terms of land use and

553 land cover as well as in terms of hydrographic and sewer networks should ideally be 554 examined.

5556 ACKNOWLEDGMENTS

556 The funding for this study came from the Campus France (B. Salavati's PhD) and 557 EC2CO-CNRS funding. This study utilized data from several sources. Daily streamflow 558 data were collected from the USGS website (available at http://waterdata.usgs.gov/). The 
1/16 degree daily rainfall- and temperature-gridded data are available from ftp://ftp.hydro.washington.edu/pub/blivneh/CONUS/. Geospatial data and classifications for stream gages maintained by the U.S. Geological Survey (USGS) called Gages II are available from http://water.usgs.gov/lookup/getspatial?gagesII_Sept2011. National Land Cover Database (NLCD) data were obtained from the Multi-Resolution Land Characteristics (MRLC) Consortium website (available at

565 http://www.mrlc.gov/about.php). Housing density data, based on David Theobald's work, were collected from the USGS. We would like to thank David Theobald and Thomas

567 Over for their assistance with housing density data.

\section{REFERENCE LIST}

Ahn, K.-H., Merwade, V., 2014. Quantifying the relative impact of climate and human activities on streamflow. J. Hydrol. 515, 257-266. https://doi.org/10.1016/j.jhydrol.2014.04.062

Alberti, M., Booth, D., Hill, K., Coburn, B., Avolio, C., Coe, S., Spirandelli, D., 2007. The impact of urban patterns on aquatic ecosystems: An empirical analysis in Puget lowland sub-basins. Landsc. Urban Plan. 80, 345-361. https://doi.org/10.1016/j.landurbplan.2006.08.001

Arnold, C.L., Gibbons, C.J., 1996. Impervious Surface Coverage: The Emergence of a Key Environmental Indicator. J. Am. Plann. Assoc. 62, 243-258. https://doi.org/10.1080/01944369608975688

Barringer, T.H., Reiser, R.G., Price, C.V., 1994. Potential Effects of Development on Flow Characteristics of Two New Jersey Streams1. JAWRA J. Am. Water Resour. Assoc. 30, 283-295. https://doi.org/10.1111/j.1752-1688.1994.tb03291.x

Bhaskar, A.S., Welty, C., Maxwell, R.M., Miller, A.J., 2015. Untangling the effects of urban development on subsurface storage in Baltimore. Water Resour. Res. 51, 1158-1181. https://doi.org/10.1002/2014WR016039

Bierwagen, B.G., Theobald, D.M., Pyke, C.R., Choate, A., Groth, P., Thomas, J.V., Morefield, P., 2010. National housing and impervious surface scenarios for integrated climate impact assessments. Proc. Natl. Acad. Sci. U. S. A. 107, 20887-20892. https://doi.org/10.1073/pnas.1002096107

Booth, D.B., Jackson, C.R., 1997. Urbanization of Aquatic Systems: Degradation Thresholds, Stormwater Detection, and the Limits of Mitigation1. JAWRA J. Am. Water Resour. Assoc. 33, 1077-1090. https://doi.org/10.1111/j.17521688.1997.tb04126.x 
602

603

604

605

606

607

608

609

610

611

612

613

614

615

616

617

618

619

620

621

622

623

624

625

626

627

628

629

630

631

632

633

634

635

636

637
Brandes, D., Cavallo, G.J., Nilson, M.L., 2005. Base flow trends in urbanizing watersheds of the Delaware River basin. J. Am. Water Resour. Assoc. 41, 13771391. https://doi.org/10.1111/j.1752-1688.2005.tb03806.x

Braud, I., Breil, P., Thollet, F., Lagouy, M., Branger, F., Jacqueminet, C., Kermadi, S., Michel, K., 2013. Evidence of the impact of urbanization on the hydrological regime of a medium-sized periurban catchment in France. J. Hydrol. 485, 5-23. https://doi.org/10.1016/j.jhydrol.2012.04.049

Brun, S.E., Band, L.E., 2000. Simulating runoff behavior in an urbanizing watershed. Comput. Environ. Urban Syst. 24, 5-22. https://doi.org/10.1016/S01989715(99)00040-X

Burns, D., Vitvar, T., McDonnell, J., Hassett, J., Duncan, J., Kendall, C., 2005. Effects of suburban development on runoff generation in the Croton River basin, New York, USA. J. Hydrol. 311, 266-281. https://doi.org/10.1016/j.jhydrol.2005.01.022

Chen, J., Theller, L., Gitau, M.W., Engel, B.A., Harbor, J.M., 2017. Urbanization impacts on surface runoff of the contiguous United States. J. Environ. Manage. 187, 470 481. https://doi.org/10.1016/j.jenvman.2016.11.017

Choi, J.-Y., Engel, B.A., Muthukrishnan, S., Harbor, J., 2003. GIS BASED LONG TERM HYDROLOGIC IMPACT EVALUATION FOR WATERSHED URBANIZATION1. JAWRA J. Am. Water Resour. Assoc. 39, 623-635. https://doi.org/10.1111/j.1752-1688.2003.tb03680.x

Claessens, L., Hopkinson, C., Rastetter, E., Vallino, J., 2006. Effect of historical changes in land use and climate on the water budget of an urbanizing watershed. Water Resour. Res. 42, W03426. https://doi.org/10.1029/2005WR004131

DeWalle, D.R., Swistock, B.R., Johnson, T.E., McGuire, K.J., 2000. Potential effects of climate change and urbanization on mean annual streamflow in the United States. Water Resour. Res. 36, 2655-2664. https://doi.org/Doi 10.1029/2000wr900134

Diem, J.E., Hill, T.C., Milligan, R.A., 2018. Diverse multi-decadal changes in streamflow within a rapidly urbanizing region. J. Hydrol. 556, 61-71. https://doi.org/10.1016/j.jhydrol.2017.10.026

Edijatno, Nascimento, N., Yang, X., Makhlouf, Z., Michel, C., 1999. GR3J: a daily watershed model with three free parameters. Hydrol. Sci. J. 44, 263-278.

Göbel, P., Stubbe, H., Weinert, M., Zimmermann, J., Fach, S., Dierkes, C., Kories, H., Messer, J., Mertsch, V., Geiger, W.F., Coldewey, W.G., 2004. Near-natural stormwater management and its effects on the water budget and groundwater surface in urban areas taking account of the hydrogeological conditions. J. Hydrol. 299, 267-283. https://doi.org/10.1016/j.jhydrol.2004.08.013

Grove, M., Harbor, J., Engel, B., 1998. Composite vs. distributed curve numbers: effects on estimates of storm runoff depths. J. Am. Water Resour. Assoc. 34, 1015-1023. https://doi.org/10.1111/j.1752-1688.1998.tb04150.x

Gupta, H.V., Kling, H., Yilmaz, K.K., Martinez, G.F., 2009. Decomposition of the mean squared error and NSE performance criteria: Implications for improving hydrological modelling. J. Hydrol. 377, 80-91.

Hawley, R.J., Bledsoe, B.P., 2011. How do flow peaks and durations change in suburbanizing semi-arid watersheds? A southern California case study. J. Hydrol. 405, 69-82. https://doi.org/10.1016/j.jhydrol.2011.05.011 
Hejazi, M.I., Moglen, G.E., 2007. Regression-based approach to low flow prediction in the Maryland Piedmont region under joint climate and land use change. Hydrol. Process. 21, 1793-1801. https://doi.org/10.1002/hyp.6374

Hibbs, B.J., Sharp, J.M., 2012. Hydrogeological Impacts of Urbanization. Environ. Eng. Geosci. 18, 3-24. https://doi.org/10.2113/gseegeosci.18.1.3

Hollis, G.E., 1977. Water yield changes after urbanization of the Canon's Brook catchment, Harlow, England. Hydrol. Sci. Bull. 22, 61-75. https://doi.org/10.1080/02626667709491694

Homer, C., Dewitz, J., Yang, L., Jin, S., Danielson, P., Xian, G., Coulston, J., Herold, N., Wickham, J., Megown, K., 2015. Completion of the 2011 National Land Cover Database for the Conterminous United States - Representing a Decade of Land Cover Change Information. Photogramm. Eng. Remote Sens. 81, 345-354. https://doi.org/10.1016/S0099-1112(15)30100-2

Huang, H., Cheng, S., Wen, J., Lee, J., 2008. Effect of growing watershed imperviousness on hydrograph parameters and peak discharge. Hydrol. Process. 22, 2075-2085. https://doi.org/10.1002/hyp.6807

Huang, S., Cheng, S., Wen, J., Lee, J., 2008. Identifying peak-imperviousness-recurrence relationships on a growing-impervious watershed, Taiwan. J. Hydrol. 362, 320 336. https://doi.org/10.1016/j.jhydrol.2008.09.002

Kauffman, G.J., Belden, A.C., Vonck, K.J., Homsey, A.R., 2009. Link between Impervious Cover and Base Flow in the White Clay Creek Wild and Scenic Watershed in Delaware. J. Hydrol. Eng. 14, 324-334. https://doi.org/10.1061/(ASCE)1084-0699(2009)14:4(324)

Klein, R.D., 1979. Urbanization and Stream Quality Impairment. JAWRA J. Am. Water Resour. Assoc. 15, 948-963. https://doi.org/10.1111/j.1752-1688.1979.tb01074.x

Konrad, C.P., Booth, D.B., 2002. Hydrologic trends associated with urban development for selected streams in the Puget Sound Basin, western Washington. US Department of the Interior, US Geological Survey.

Konrad, C.P., Booth, D.B., Burges, S.J., 2005. Effects of urban development in the Puget Lowland, Washington, on interannual streamflow patterns: Consequences for channel form and streambed disturbance. Water Resour. Res. 41, W07009. https://doi.org/10.1029/2005WR004097

Kuczera, G., Raper, G., Brah, N., Jayasuriya, M., 1993. Modeling Yield Changes After Strip Thinning in a Mountain Ash Catchment - an Exercise in Catchment Model Validation. J. Hydrol. 150, 433-457. https://doi.org/10.1016/00221694(93)90120-X

Leopold, L.B., 1968. Hydrology for urban land planning - A guidebook on the hydrologic effects of urban land use (USGS Numbered Series No. 554), Circular. U.S. Geological Survey, Reston, VA.

Li, H., Zhang, Y., Vaze, J., Wang, B., 2012. Separating effects of vegetation change and climate variability using hydrological modelling and sensitivity-based approaches. J. Hydrol. 420-421, 403-418. https://doi.org/10.1016/j.jhydrol.2011.12.033

Livneh, B., Rosenberg, E.A., Lin, C., Nijssen, B., Mishra, V., Andreadis, K.M., Maurer, E.P., Lettenmaier, D.P., 2013. A Long-Term Hydrologically Based Dataset of Land Surface Fluxes and States for the Conterminous United States: Update and Extensions*. J. Clim. 26, 9384-9392. https://doi.org/10.1175/JCLI-D-12-00508.1 
Mejía, A., Rossel, F., Gironás, J., Jovanovic, T., 2015. Anthropogenic controls from urban growth on flow regimes. Adv. Water Resour. 84, 125-135. https://doi.org/10.1016/j.advwatres.2015.08.010

Mejía, A.I., Moglen, G.E., 2010a. Impact of the spatial distribution of imperviousness on the hydrologic response of an urbanizing basin. Hydrol. Process. 24, 3359-3373. https://doi.org/10.1002/hyp.7755

Mejía, A.I., Moglen, G.E., 2010b. Spatial distribution of imperviousness and the spacetime variability of rainfall, runoff generation, and routing. Water Resour. Res. 46. https://doi.org/10.1029/2009WR008568

Miller, J.D., Hess, T., 2017. Urbanisation impacts on storm runoff along a rural-urban gradient. J. Hydrol. 552, 474-489. https://doi.org/10.1016/j.jhydrol.2017.06.025

Miller, J.D., Kim, H., Kjeldsen, T.R., Packman, J., Grebby, S., Dearden, R., 2014. Assessing the impact of urbanization on storm runoff in a pen-urban catchment using historical change in impervious cover. J. Hydrol. 515, 59-70. https://doi.org/10.1016/j.jhydrol.2014.04.011

Ogden, F.L., Raj Pradhan, N., Downer, C.W., Zahner, J.A., 2011. Relative importance of impervious area, drainage density, width function, and subsurface storm drainage on flood runoff from an urbanized catchment. Water Resour. Res. 47. https://doi.org/10.1029/2011WR010550

Oudin, L., Hervieu, F., Michel, C., Perrin, C., Andréassian, V., Anctil, F., Loumagne, C., 2005. Which potential evapotranspiration input for a lumped rainfall-runoff model? - Part 2 - Towards a simple and efficient potential evapotranspiration model for rainfall-runoff modelling. J. Hydrol. 303, 290-306.

Over, T.M., Saito, R.J., Soong, D.T., 2016. Adjusting annual maximum peak discharges at selected stations in northeastern Illinois for changes in land-use conditions (Report No. 2016-5049), Scientific Investigations Report. Reston, VA. https://doi.org/10.3133/sir20165049

Perrin, C., Michel, C., Andréassian, V., 2003. Improvement of a parsimonious model for streamflow simulation. J. Hydrol. 279, 275-289.

Petchprayoon, P., Blanken, P.D., Ekkawatpanit, C., Hussein, K., 2010. Hydrological impacts of land use/land cover change in a large river basin in central-northern Thailand. Int. J. Climatol. 30, 1917-1930. https://doi.org/10.1002/joc.2131

Poncelet, C., Merz, R., Merz, B., Parajka, J., Oudin, L., Andréassian, V., Perrin, C., 2017. Process-based interpretation of conceptual hydrological model performance using a multinational catchment set. Water Resour. Res. 53, 7247-7268. https://doi.org/10.1002/2016WR019991

Prosdocimi, I., Kjeldsen, T.R., Miller, J.D., 2015. Detection and attribution of urbanization effect on flood extremes using nonstationary flood-frequency models. Water Resour. Res. 51, 4244-4262. https://doi.org/10.1002/2015WR017065

Putro, B., Kjeldsen, T.R., Hutchins, M.G., Miller, J., 2016. An empirical investigation of climate and land-use effects on water quantity and quality in two urbanising catchments in the southern United Kingdom. Sci. Total Environ. 548-549, 164172. https://doi.org/10.1016/j.scitotenv.2015.12.132 
Rose, S., Peters, N.E., 2001. Effects of urbanization on streamflow in the Atlanta area (Georgia, USA): a comparative hydrological approach. Hydrol. Process. 15, 1441-1457. https://doi.org/10.1002/hyp.218

Rougé, C., Cai, X., 2014. Crossing-scale hydrological impacts of urbanization and climate variability in the Greater Chicago Area. J. Hydrol. 517, 13-27. https://doi.org/10.1016/j.jhydrol.2014.05.005

Salavati, B., Oudin, L., Furusho-Percot, C., Ribstein, P., 2016. Modeling approaches to detect land-use changes: Urbanization analyzed on a set of 43 US catchments. J. Hydrol. 538, 138-151. https://doi.org/10.1016/j.jhydrol.2016.04.010

Salvadore, E., Bronders, J., Batelaan, O., 2015. Hydrological modelling of urbanized catchments: A review and future directions. J. Hydrol. 529, 62-81. https://doi.org/10.1016/j.jhydrol.2015.06.028

Schueler, T.R., Fraley-McNeal, L., Cappiella, K., 2009. Is Impervious Cover Still Important? Review of Recent Research. J. Hydrol. Eng. 14, 309-315. https://doi.org/10.1061/(ASCE)1084-0699(2009)14:4(309)

Schwartz, S.S., Smith, B., 2014. Slowflow fingerprints of urban hydrology. J. Hydrol. 515, 116-128. https://doi.org/10.1016/j.jhydrol.2014.04.019

Seibert, J., McDonnell, J.J., 2010. Land-cover impacts on streamflow: a change-detection modelling approach that incorporates parameter uncertainty. Hydrol. Sci. J. 55, 316-332. https://doi.org/10.1080/02626661003683264

Sheeder, S.A., Ross, J.D., Carlson, T.N., 2002. Dual urban and rural hydrograph signals in three small watersheds. J. Am. Water Resour. Assoc. 38, 1027-1040. https://doi.org/10.1111/j.1752-1688.2002.tb05543.x

Simmons, D.L., Reynolds, R.J., 1982. Effects of Urbanization on Base Flow of Selected South-Shore Streams, Long Island, New York1. JAWRA J. Am. Water Resour. Assoc. 18, 797-805. https://doi.org/10.1111/j.1752-1688.1982.tb00075.x

Tetzlaff, D., Grottker, M., Leibundgut, C., 2005. Hydrological criteria to assess changes of flow dynamic in urban impacted catchments. Phys. Chem. Earth Parts ABC, Integrated Water Resource Assessment 30, 426-431. https://doi.org/10.1016/j.pce.2005.06.008

Theobald, D.M., 2005. Landscape Patterns of Exurban Growth in the USA from 1980 to 2020. Ecol. Soc. 10, art32.

Theobald, D.M., Goetz, S.J., Norman, J.B., Jantz, P., 2009. Watersheds at Risk to Increased Impervious Surface Cover in the Conterminous United States. J. Hydrol. Eng. 14, 362-368. https://doi.org/10.1061/(ASCE)10840699(2009)14:4(362)

Tong, S.T.Y., 1990. The hydrologic effects of urban land use: A case study of the little Miami River Basin. Landsc. Urban Plan. 19, 99-105. https://doi.org/10.1016/0169-2046(90)90037-3

Trinh, D.H., Chui, T.F.M., 2013. Assessing the hydrologic restoration of an urbanized area via an integrated distributed hydrological model. Hydrol. Earth Syst. Sci. 17, 4789-4801. https://doi.org/10.5194/hess-17-4789-2013

United Nations, 2014. World Urbanization Prospects: The 2014 Revision, Highlights. Department of Economic and Social Affairs, Population Division, United Nations. 
Valéry, A., Andréassian, V., Perrin, C., 2014a. 'As simple as possible but not simpler': What is useful in a temperature-based snow-accounting routine? Part 1 Comparison of six snow accounting routines on 380 catchments. J. Hydrol. 517, 1166-1175. https://doi.org/10.1016/j.jhydrol.2014.04.059

Valéry, A., Andréassian, V., Perrin, C., 2014b. 'As simple as possible but not simpler': What is useful in a temperature-based snow-accounting routine? Part 2 Sensitivity analysis of the Cemaneige snow accounting routine on 380 $\begin{array}{llll}\text { catchments. } & \text { J. Hydrol. } & \text { 1176-1187. }\end{array}$ https://doi.org/10.1016/j.jhydrol.2014.04.058

Walsh, C., Mac Nally, R., 2003. The hier.part package. Hierarchical Partitioning R Proj. Stat. Comput. URL Httpcran R-Proj. Org.

Wang, D., Hejazi, M., 2011. Quantifying the relative contribution of the climate and direct human impacts on mean annual streamflow in the contiguous United States. Water Resour. Res. 47, W00J12. https://doi.org/10.1029/2010WR010283

Xian, G., Homer, C., Dewitz, J., Fry, J., Hossain, N., Wickham, J., 2011. Change of impervious surface area between 2001 and 2006 in the conterminous United States. Photogramm. Eng. Remote Sens. 77, 758-762.

Yang, G., Bowling, L.C., Cherkauer, K.A., Pijanowski, B.C., Niyogi, D., 2010. Hydroclimatic Response of Watersheds to Urban Intensity: An Observational and Modeling-Based Analysis for the White River Basin, Indiana. J. Hydrometeorol. 11, 122-138. https://doi.org/10.1175/2009JHM1143.1

Yang, L., Smith, J.A., Wright, D.B., Baeck, M.L., Villarini, G., Tian, F., Hu, H., 2013. Urbanization and Climate Change: An Examination of Nonstationarities in Urban Flooding. J. Hydrometeorol. 14, 1791-1809. https://doi.org/10.1175/JHM-D-12095.1 


\section{FigURE LEGENDS}

Figure 1: Structure of the GR4J rainfall-runoff model used (Perrin et al., 2003) coupled with CemaNeige (Valéry et al., 2014a, 2014b).

Figure 2: Fraction of urban areas and catchment imperviousness from NLCD database and HD maps on the 430 urban catchments. The NLCD data for urban areas corresponds to the sum of the developed area classes (21-24) for the year 2011, and the catchment imperviousness corresponds to the 2011 imperviousness map; HD estimates were derived from the $2010 \mathrm{HD}$ map using the reclassification proposed in Table 2.

Figure 3: Distribution of the mean catchment imperviousness for the pre-and posturbanization periods and TIA evolutions.

Figure 4: Location of the 142 urban catchments studied.

Figure 5: Catchment urbanization patterns for the preurbanization and posturbanization periods. The boxplots represent the distribution of the variables over the 142 catchments studied. The bottom and top of the boxes represent the first and third quartiles and the whiskers represent the 1.5 interquartile range...... 23

Figure 6: Two contrasted examples of catchment urbanization patterns. For a similar extent of urban area, the Quinnipiac River at Wallingford (top) presents more fragmented urban and nonurban areas than the Whippany River at Morristown (bottom) for which concentrated urban areas are located in the downstream part of the catchment.

Figure 7: Model calibration efficiency over the 142 catchments studied. KGE(sqrtQ) is the Kling-Gupta efficiency criterion on root-squared transformed daily flow, R2.Q05 R2.Q95 and R2.QMA are the coefficients of determination of annual streamflow characteristics. The bottom and top of the boxes represent the first and third quartiles and the whiskers represent the 1.5 interquartile range.

Figure 8: Results of the split sample test applied on the preurbanization period for the 142 studied catchments. KGE(sqrtQ) is the Kling-Gupta efficiency criterion on root-squared transformed daily flow. The bottom and top of the boxes represent the first and third quartiles and the whiskers represent the 1.5 interquartile range.

Figure 9: Relative changes for low (Q05) high (Q95) and mean (QMA) flow characteristics of the 142 catchments studied. Values are given for four TIA increase classes $(5.0-6.3 \%, 6.3-9.8 \%, 9.8-15.5 \%, 15.5-27 \%)$, each class representing $35-36$ catchments.

Figure 10: Hierarchical partitioning indicating the relative contribution (\%) of each predictor to the variance explained by the linear models relating changes of flow characteristics and urbanization characteristics over the 142 urban catchments studied. 


\section{TABLES}

Table 1: Summary of studies on the hydrological impact of urbanization. Studies involving hydrological modeling are in bold.................................................. 4

Table 2: Reclassification of housing density data to estimate urban areas and imperviousness

Table 3: Urban catchment characteristics used to analyze the different urbanization patterns over the catchment set.

Table 4: Results obtained from the stepwise selection procedure. The coefficients displayed in the table are those that were extracted from the best model (through BIC) for each flow characteristic. Stars represents the p-value range '***' $<0.001$, '**' $<0.01$, '*' $<0.05$. 